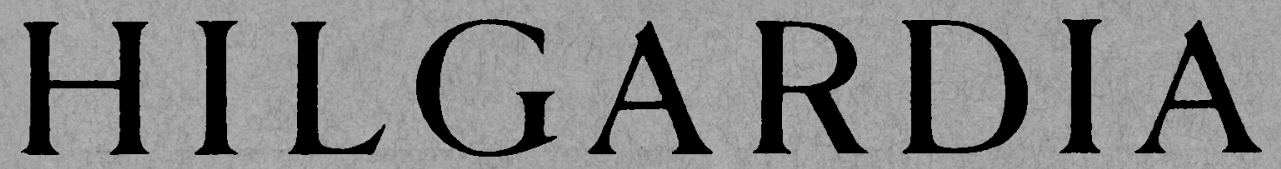

A Journal of Agricultural Science Published by the California Agricultural Experiment Station

\title{
NITRIFICATION OF AMMONIACAL FERTILIZERS IN SOME CALIFORNIA SOILS
}

\author{
F. E. BROADBENT, K. B. TYLER, \\ and G. N. HILL
}

UNIVERSITY OF CALIFORNIA - BERKELEY, CALIFORNIA 
Because of the manner in which ammonium fertilizers are applied and the tendency of the ammonium ion as well as of free ammonia to be absorbed at the point of contact with soil colloids, localized high concentrations are the rule rather than the exception. A concentration gradient is produced with a maximum along the line of application.

In experiments intended to simulate a cross section of a fertilizer band, it was shown that nitrification is rapid and complete at low ammonium concentrations such as would occur at the edge of a band. At higher concentrations, inhibition of nitrification may result from one or more causes: (1) excessively high $\mathrm{pH}$ resulting from application of alkaline materials; (2) excessively low $\mathrm{pH}$ resulting from formation of nitrous and nitric acids; (3) presence of free ammonia, exerting selective inhibition on the nitrate-forming bacteria; (4) salt effect, resulting in osmotic concentrations too high for optimal activity of nitrifying bacteria.

The data of these experiments show that, under optimum conditions, nitrification is an extraordinarily rapid process. This fact should prove helpful in interpreting numerous field observations involving either response or lack of response to ammonium fertilizers. If moisture, $\mathrm{pH}$, and temperature conditions of the soil are satisfactory, it may be assumed with confidence that nitrate will be produced from an added ammonium fertilizer in sufficient quantity to keep pace with the needs of growing plants in most agricultural soils. 


\title{
$\begin{array}{lllllllll}H & \text { I } & \text { L } & G & A & R & D & \text { I } & \text { A }\end{array}$
}

A Journal of Agricultural Science Published by

the California Agricultural Experiment Station

VOL. 27

DECEMBER, 1957

No. 9

\section{NITRIFICATION OF AMMONIACAL FERTILIZERS IN SOME CALIFORNIA SOILS ${ }^{1,2}$}

\author{
F. E. BROADBENT, ${ }^{3}$ K. B. TYLER, ${ }^{4}$ and G. N. HILL"
}

\section{INTRODUCTION}

INCREASED USE of ammoniacal fertilizers has renewed interest in the nitrification process, which involves oxidation of ammonium nitrogen to nitrate by soil bacteria. In particular, new problems have been raised by the development of anhydrous ammonia and aqueous solutions of ammonia as major nitrogen fertilizers. These materials, as applied, result in very high concentrations of ammonia nitrogen in a small band. Several aspects of anhydrous ammonia fertilization in sandy Florida soils have been dealt with in a series of recent papers (Blue and Eno, 1954 ; Eno and Blue, 1954; Eno, Blue, and Good, 1955). ${ }^{\circ}$ This work emphasizes the effect of anhydrous ammonia on soil $\mathrm{pH}$, and discusses the partial sterilizing action of the fertilizer on the soil population in general and its effect on the nitrification process in particular.

Although nitrification and the nitrifying bacteria have been the subject of a great many investigations since the famous experiments of Schloesing and Müntz (1877), very little of the published material discusses work done under conditions simulating modern fertilizer practice. The present paper reports a series of experiments conducted to provide information on several typical California soils. These experiments had four objectives: (1) to determine the effect on nitrification of ammoniacal nitrogen concentration; (2) to discover what concentrations of ammonia and ammonium ion inhibit nitrification; (3) to measure nitrification rates of different fertilizer materials; and (4) to follow $\mathrm{pH}$ changes during nitrification and to establish limiting $\mathrm{pH}$ values for the process, if possible.

\footnotetext{
${ }^{1}$ Received for publication April 26, 1957.

2 The authors wish to express their appreciation to Brea Chemicals, Inc., for a grantin-aid in support of this investigation.

${ }^{3}$ Associate Professor of Soil Microbiology and Associate Soil Microbiologist in the Experiment Station, Davis.

${ }^{4}$ Assistant Olericulturist, Department of Vegetable Crops, Riverside.

${ }^{5}$ Laboratory Technician, Department of Soils and Plant Nutrition, Davis.

${ }^{\circ}$ See "Literature Cited" for citations referred to in text by author and date.
} 


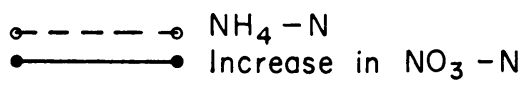

$\mathrm{NH}_{4} \mathrm{OH}$
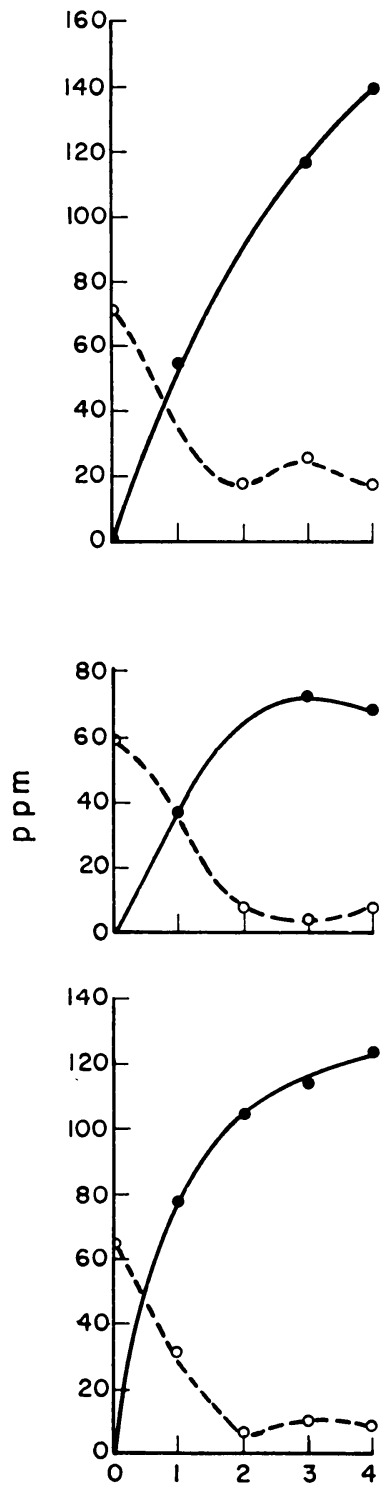

$\left(\mathrm{NH}_{4}\right)_{2} \mathrm{SO}_{4}$

$\mathrm{NH}_{4} \mathrm{NO}_{3}$

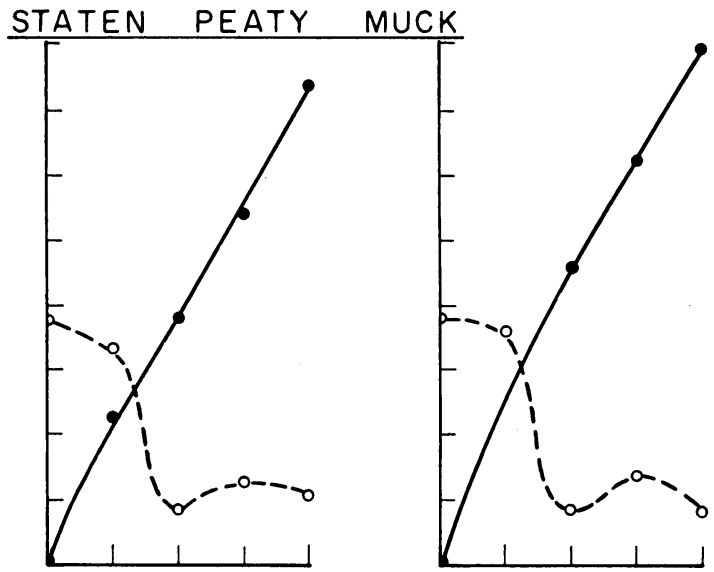

HANFORD SANDY LOAM

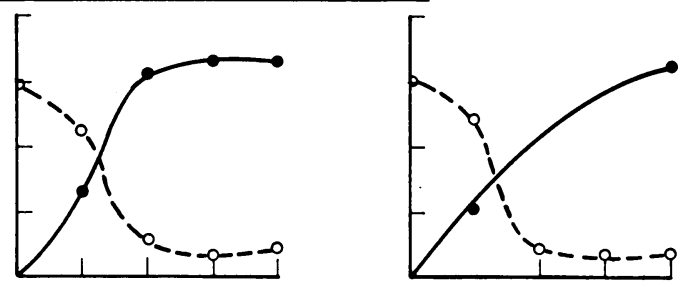

SACRAMENTO CLAY
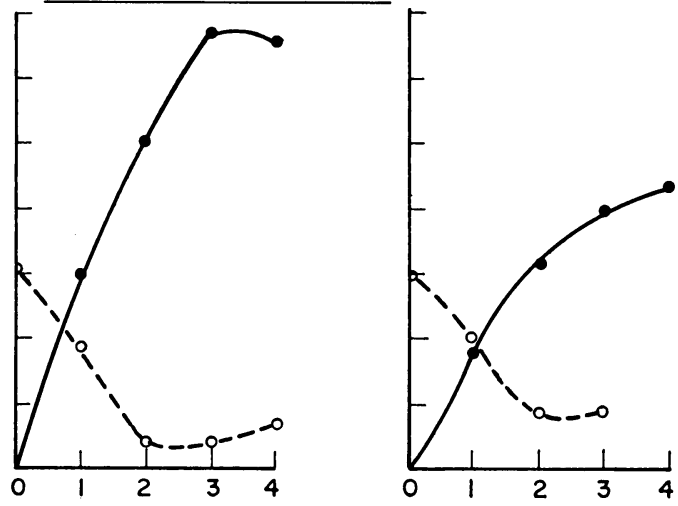

WEEKS

Fig. 1. Inorganic nitrogen changes in three acid soils receiving $50 \mathrm{ppm}$ ammonium nitrogen. 


\section{METHODS}

Six series typical of soils which commonly receive heavy fertilizer applications in vegetable and field crop production were selected:

1. Sacramento clay, an imperfectly drained basin soil, $\mathrm{pH} 5.57$ (glass electrode measurement on 1:1 soil:water suspension). This particular soil is more acid than is typical of the series.

2. Hanford sandy loam, an alluvial soil formed from granitic rock, $\mathrm{pH}$ 6.39.

3 . Staten peaty muck, an organic soil from the Sacramento-San Joaquin delta region, $\mathrm{pH} 5.44$.

4. Salinas clay, formed from mixed alluvium, calcareous to the surface, $\mathrm{pH} 8.10$.

5. Yolo loam, formed from sedimentary rock alluvium, $\mathrm{pH} 7.61$.

6. Imperial clay, a desert alluvial soil, calcareous, $\mathrm{pH} 8.00$.

A factorial experiment was set up to include the six soils; six levels of application-0, 50,100, 200, 400, and $800 \mathrm{ppm}$ of ammonia nitrogen; three fertilizers-ammonium hydroxide, ammonium sulfate, and ammonium nitrate; and seven sampling dates- $0,1,2,3,4,6$, and 8 weeks.

The fertilizer materials were dissolved in sufficient water to bring the soils approximately to field capacity, and the solutions were pipetted into Erlenmeyer flasks containing 50-gram samples of air-dry soil. Care was taken to make the wetting process as uniform as possible. Two samples were set up for each treatment and date although, in several instances, the samplings were not continued beyond four weeks since all the added fertilizer was nitrified by that time. The soils were incubated in a constant temperature chamber at $75^{\circ} \pm 0.2^{\circ} \mathrm{F}$., with a slow stream of air at 100 per cent relative humidity passing through the flasks to insure adequate aeration and prevent drying out. At the end of a given incubation period the samples were removed. Sufficient water was added to make a 1:1 soil:water suspension, except for the peaty muck which required a 1:2 ratio. The suspensions were shaken thoroughly, and the $\mathrm{pH}$ was determined by means of the glass electrode. The samples were then shaken for several minutes with $50 \mathrm{ml}$ of extracting solution containing $1 \mathrm{~N} \mathrm{NaCl}$ and $\mathrm{N} / 10 \mathrm{HCl}$. The $\mathrm{HCl}$ was omitted in extracting the calcareous soils. The soil suspensions were transferred to Büchner funnels, washed with $100 \mathrm{ml}$ of extracting solution in several portions, and finally washed with water. The filtrate was made to $250 \mathrm{ml}$. Ammonia nitrogen was determined by distillation of an aliquot on a semimicro Kjeldahl apparatus. After the ammonia nitrogen was distilled over, the receiver was changed, Devarda's alloy and additional water were added to the distillation flask, and the nitrite plus nitrate was determined by a second distillation. Nitrite was determined colorimetrically on a separate aliquot of the original extract.

\section{EXPERIMENTAL RESULTS}

Nitrification in Initially Acid Soils. Changes in level of ammonia nitrogen and increases in nitrate nitrogen for the Staten, Hanford, and Sacramento soils are shown in figures 1 to 5, arranged in order of increasing level of application. This series of figures might be considered to represent a cross section of a fertilizer band, with the lowest concentration taken at the edge 


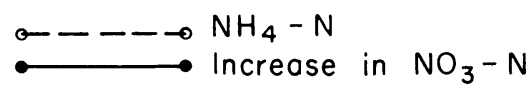

$\mathrm{NH}_{4} \mathrm{OH}$
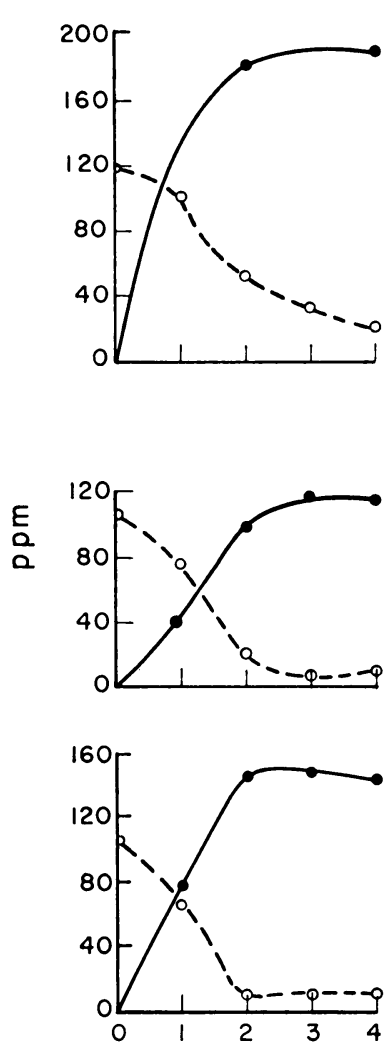

$\left(\mathrm{NH}_{4}\right)_{2} \mathrm{SO}_{4}$ $\mathrm{NH}_{4} \mathrm{NO}_{3}$

\section{STATEN PEATY MUCK}

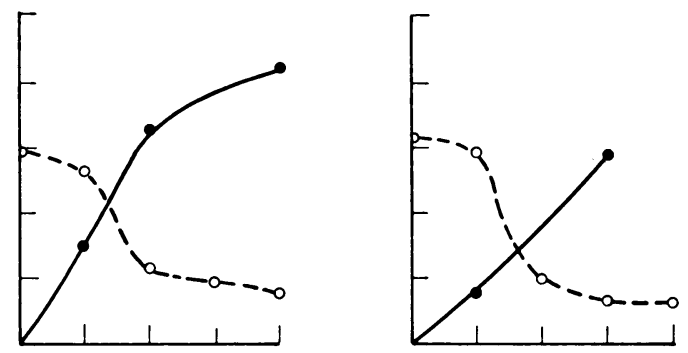

HANFORD SANDY LOAM
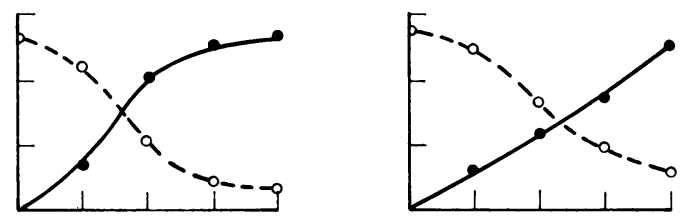

SACRAMENTO CLAY
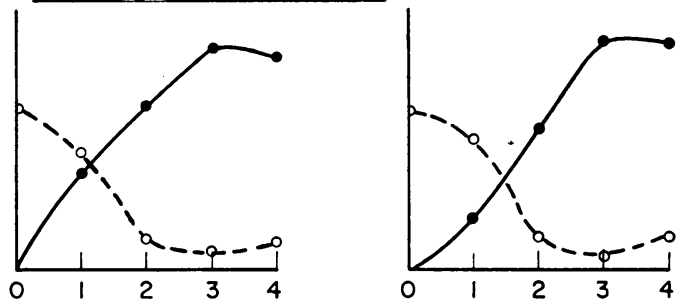

WEEKS

Fig. 2. Inorganic nitrogen changes in three acid soils receiving $100 \mathrm{ppm}$ ammonium nitrogen.

and the highest concentration near the center. At $50 \mathrm{ppm}$ (fig. 1), all three fertilizers were converted quite rapidly to nitrate, and the increase in nitrate was invariably more than $50 \mathrm{ppm}$, due to ammonification and subsequent oxidation of organic nitrogen during the incubation period in addition to essentially quantitative oxidation of the added ammonium-nitrogen. At 100 ppm (fig. 2), the same general observations apply, but there is some indication that ammonium as the hydroxide was oxidized more rapidly than as the sulfate and nitrate. The latter observation is clearly apparent at 200 and $400 \mathrm{ppm}$ (figs. 3 and 4), particularly in the poorly buffered Hanford 


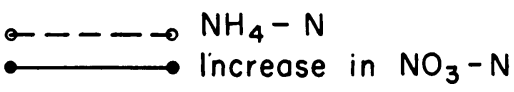

$\mathrm{NH}_{4} \mathrm{OH}$
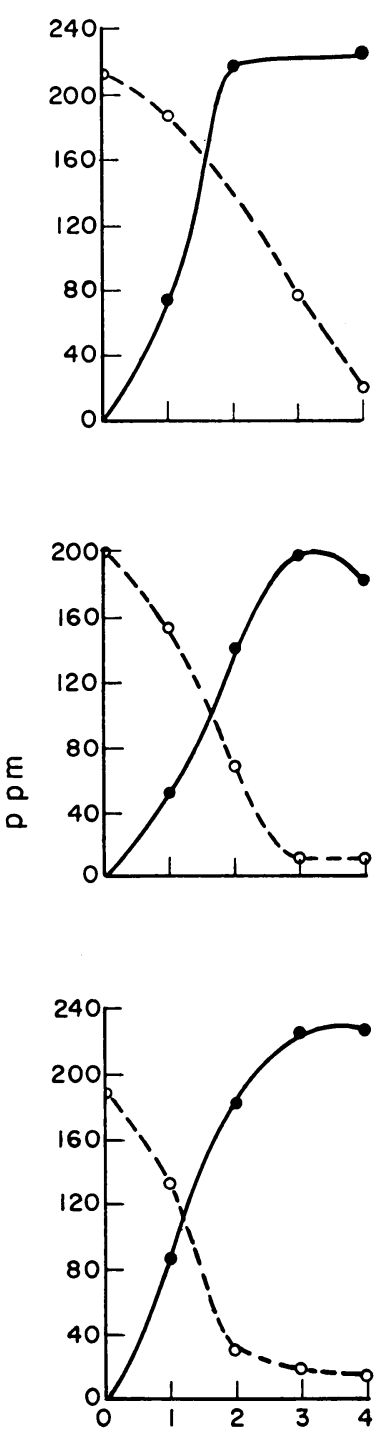

$\left(\mathrm{NH}_{4}\right)_{2} \mathrm{SO}_{4}$ $\mathrm{NH}_{4} \mathrm{NO}_{3}$

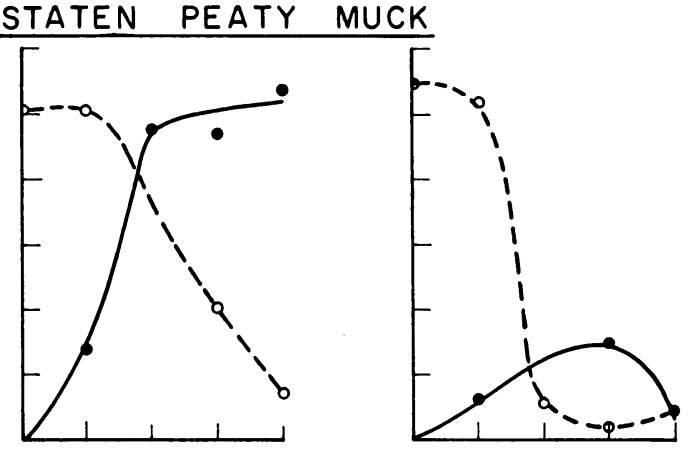

\section{HANFORD SANDY LOAM}
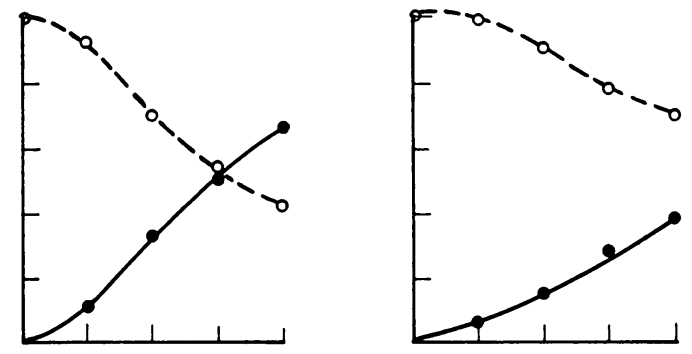

SACRAMENTO CLAY
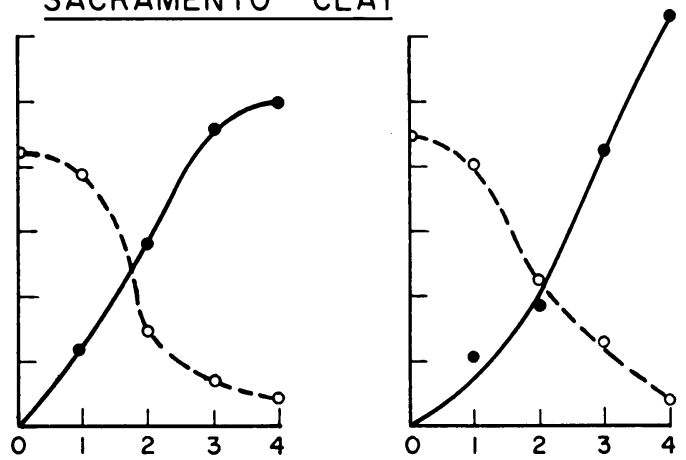

WEEKS

Fig. 3. Inorganic nitrogen changes in three acid soils receiving $200 \mathrm{ppm}$ ammonium nitrogen. 


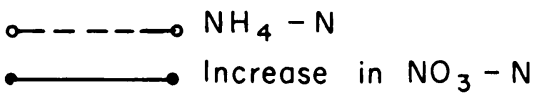

$\mathrm{NH}_{4} \mathrm{OH}$

$\left(\mathrm{NH}_{4}\right)_{2} \mathrm{SO}_{4}$ $\mathrm{NH}_{4} \mathrm{NO}_{3}$

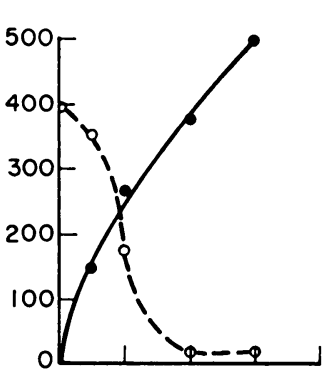

STATEN PEATY MUCK
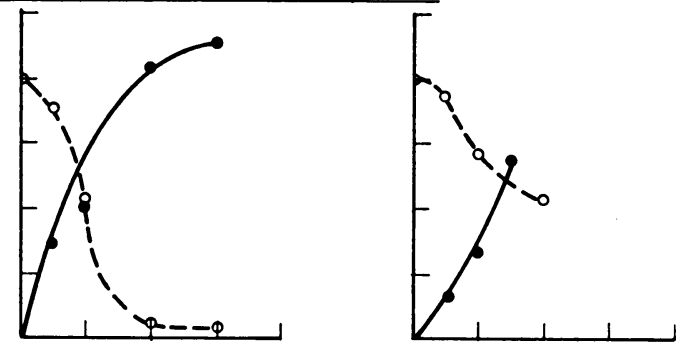

$\varepsilon$

a
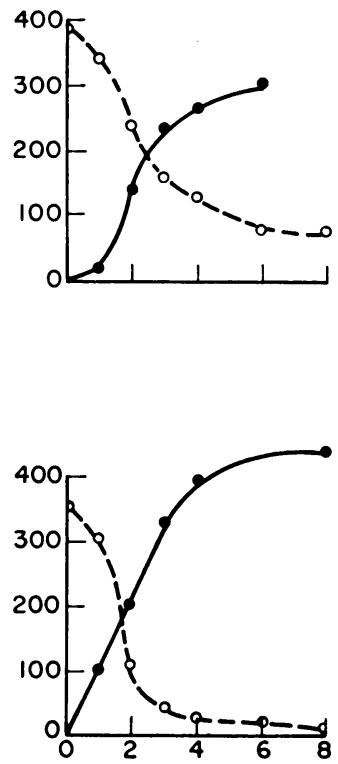

\section{HANFORD SANDY LOAM}
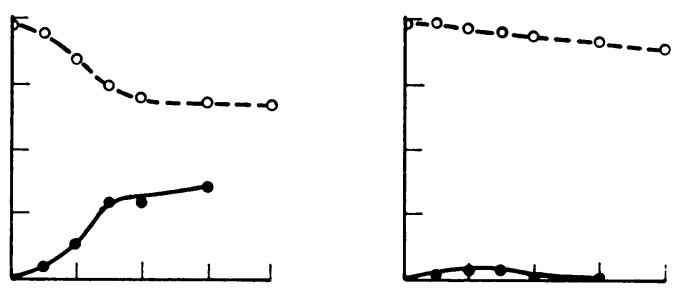

\section{SACRAMENTO CLAY}
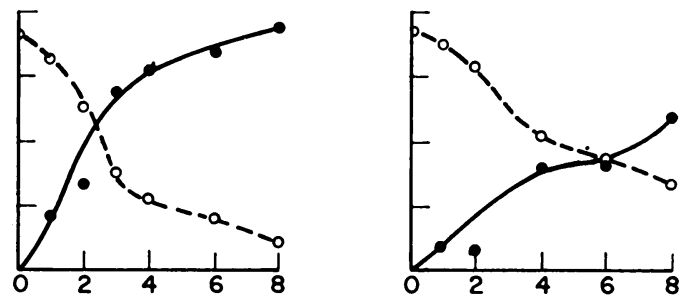

WEEKS

Fig. 4. Inorganic nitrogen changes in three acid soils receiving $400 \mathrm{ppm}$ ammonium nitrogen.

sandy loam. At $800 \mathrm{ppm}$ (fig. 5), nitrification was almost completely inhibited in the Hanford soil receiving $\mathrm{NH}_{4} \mathrm{OH}$. The decline in the $\mathrm{NH}_{4}-\mathrm{N}$ curve in this case can be attributed to volatilization losses. Some oxidation of $\left(\mathrm{NH}_{4}\right)_{2} \mathrm{SO}_{4}$ occurred in the Hanford, but the $\mathrm{NH}_{4} \mathrm{NO}_{3}$ remained unchanged. 
Even in the heavy Sacramento clay, ammonium added as $\left(\mathrm{NH}_{4}\right)_{2} \mathrm{SO}_{4}$ and $\mathrm{NH}_{4} \mathrm{NO}_{3}$ was slow to nitrify.

Information on the relative inhibitory effects of still higher concentrations of ammonium fertilizers in these three soils are summarized in table 1 . The observations were made at the end of an arbitrarily selected four-week period, and this fact must be kept in mind in their interpretation. For example,

TABLE 1

RELATIVE INHIBITORY EFFECT ON NITRIFICATION OF HIGH AMMONIUM FERTILIZER CONCENTRATIONS IN THREE INITIALLY ACID SOILS

(Observations made at $\epsilon$ nd of four weeks)

\begin{tabular}{|c|c|c|c|c|c|c|c|}
\hline Soil & Source of $N$ & $\mathrm{~N}$ added & Final $\mathrm{pH}$ & $\mathrm{NH}_{4}-\mathrm{N}$ & $\mathrm{NO}_{2}-\mathrm{N}$ & $\begin{array}{l}\text { Increase } \\
\text { in } \mathrm{NO}_{3}-\mathrm{N}\end{array}$ & $\begin{array}{c}\text { Per cent } \\
\text { of maximum } \\
\begin{array}{c}\text { nitrification } \\
\text { rate* }\end{array}\end{array}$ \\
\hline \multirow{3}{*}{ Sacramento clay } & $\mathrm{NH}_{4} \mathrm{OH}$ & $\begin{array}{l}\text { ppm } \\
1,600 \\
3,200 \\
4,000\end{array}$ & $\begin{array}{l}6.91 \\
8.38 \\
8.75\end{array}$ & $\begin{array}{r}p p^{m} \\
897 \\
2,100 \\
2,633\end{array}$ & $\begin{array}{c}p p m \\
149 \\
61 \\
1\end{array}$ & $\begin{array}{c}p p m \\
125 \\
95 \\
28\end{array}$ & $\begin{array}{l}31 \\
23 \\
15\end{array}$ \\
\hline & $\left(\mathrm{NH}_{4}\right)_{2} \mathrm{SO}$ & $\begin{array}{l}1,600 \\
3,200\end{array}$ & $\begin{array}{l}4.33 \\
4.79\end{array}$ & $\begin{array}{l}1,103 \\
2,780\end{array}$ & $\begin{array}{l}0 \\
0\end{array}$ & $\begin{array}{l}291 \\
157\end{array}$ & $\begin{array}{l}54 \\
26\end{array}$ \\
\hline & $\mathrm{NH}_{4} \mathrm{NO}_{3}$ & $\begin{array}{r}800 \\
1,600 \\
3,200\end{array}$ & $\begin{array}{l}4.90 \\
5.03 \\
4.93\end{array}$ & $\begin{array}{r}627 \\
1,400 \\
2,965\end{array}$ & $\begin{array}{l}0 \\
0 \\
0\end{array}$ & $\begin{array}{r}53 \\
0 \\
0\end{array}$ & $\begin{array}{r}13 \\
0 \\
0\end{array}$ \\
\hline \multirow{3}{*}{ Hanford sandy loam } & $\mathrm{NH}_{4} \mathrm{OH}$ & 800 & 9.04 & 668 & 0 & 0 & 0 \\
\hline & $\left(\mathrm{NH}_{4}\right)_{2} \mathrm{SO}_{4}$ & $\begin{array}{r}400 \\
800 \\
1,600\end{array}$ & $\begin{array}{l}4.66 \\
4.86 \\
5.78\end{array}$ & $\begin{array}{r}279 \\
698 \\
1,540\end{array}$ & $\begin{array}{l}0 \\
0 \\
0\end{array}$ & $\begin{array}{r}114 \\
90 \\
73\end{array}$ & $\begin{array}{l}45 \\
35 \\
29\end{array}$ \\
\hline & $\mathrm{NH}_{4} \mathrm{NO}_{3}$ & $\begin{array}{l}200 \\
400 \\
800\end{array}$ & $\begin{array}{l}4.99 \\
5.47 \\
5.81\end{array}$ & $\begin{array}{l}142 \\
374 \\
792\end{array}$ & $\begin{array}{l}0 \\
0 \\
0\end{array}$ & $\begin{array}{r}77 \\
0 \\
0\end{array}$ & $\begin{array}{r}60 \\
0 \\
0\end{array}$ \\
\hline \multirow{2}{*}{ Staten peaty muck } & $\mathrm{NH}_{4} \mathrm{OH}$ & 3,200 & 5. 30 & 897 & 0 & 512 & 60 \\
\hline & $\left(\mathrm{NH}_{4}\right)_{2} \mathrm{SO}_{4}$ & 3,200 & 4.99 & 1,206 & 0 & 91 & 14 \\
\hline
\end{tabular}

* Maximum rate taken as highest rate observed for a given fertilizer in figures 1 to 5 .

in the Hanford sandy loam, $800 \mathrm{ppm}$ nitrogen as $\mathrm{NH}_{4} \mathrm{OH}$ completely inhibited nitrification during the four-week period, but after eight weeks a small amount of nitrite appeared, indicating the beginning of the nitrification process. Table 1 emphasizes the variability among soils and types of fertilizers with respect to the degree of inhibition produced at a given concentration. This variability is due in part to the fact that the causes of inhibition (see pp. 265-266) are not the same in every case.

Nitrification in Initially Alkaline Soils. Figures 6 to 10 show the course of nitrification in the Yolo, Imperial, and Salinas soils. $\Lambda$ t $50 \mathrm{ppm}$ (fig. 6), the added ammonium was rapidly converted to nitrate, but the occurrence of small amounts of nitrite at the one-week sampling date in Imperial clay was not observed in the initially acid soils. At $100 \mathrm{ppm}$ (fig. 7), the nitri- 


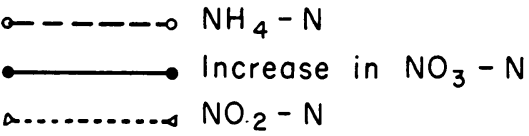

$\mathrm{NH}_{4} \mathrm{OH}$
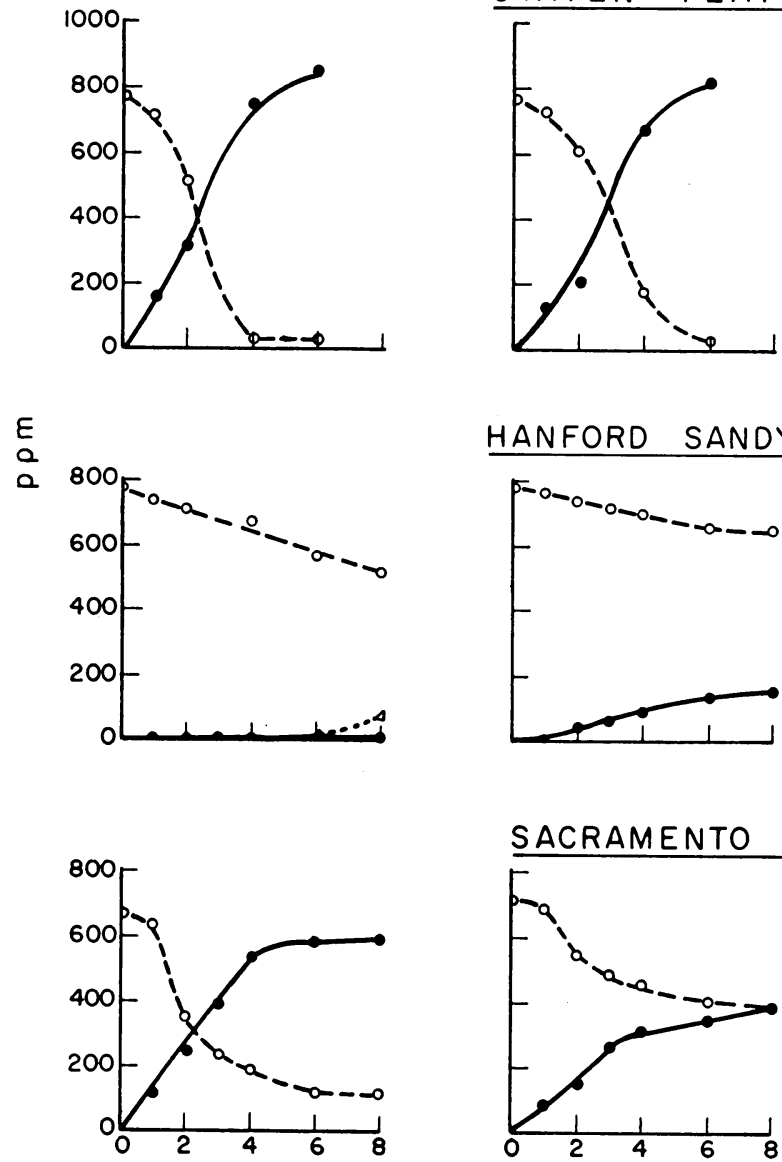

\section{HANFORD SANDY LOAM}

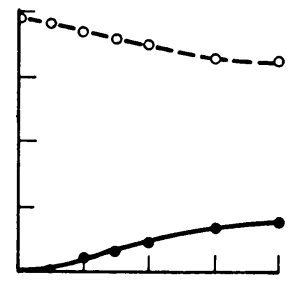

SACRAMENTO CLAY
$\left(\mathrm{NH}_{4}\right)_{2} \mathrm{SO}_{4}$ $\mathrm{NH}_{4} \mathrm{NO}_{3}$
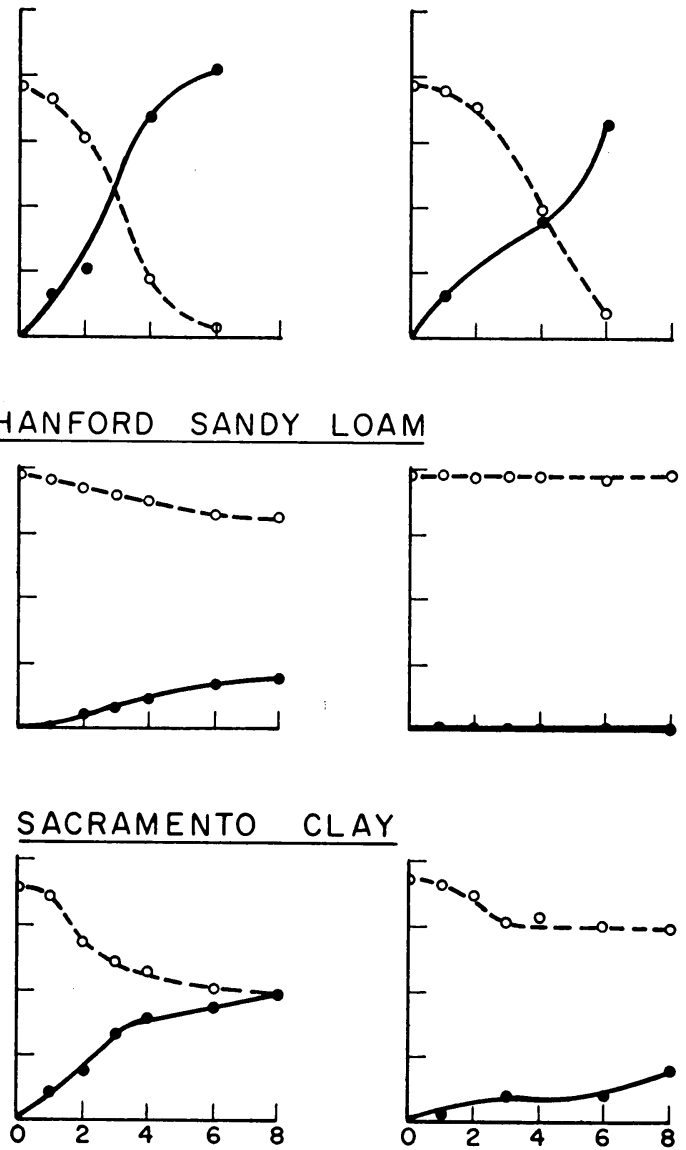

WEEKS

Fig. 5. Inorganic nitrogen changes in three acid soils receiving $800 \mathrm{ppm}$ ammonium nitrogen.

fication rates of ammonium sulfate and ammonium nitrate were noticeably slower than that of the hydroxide, and the occurrence of nitrite in Imperial clay was more pronounced. These same observations are applicable at 200 ppm (fig. 8). In figure 9, the differences among nitrification rates of the three fertilizers were quite large, and the 400 -ppm application of ammonium 
hydroxide caused the transitory appearance of nitrite in Salinas clay. All three fertilizers induced temporary nitrite formation in Imperial clay. At $800 \mathrm{ppm}$ (fig. 10), nitrification of ammonium sulfate and nitrate was strongly inhibited in Yolo loam, and nitrite occurred with all three fertilizers in the Imperial and Salinas soils. In the Imperial soil the increase in nitrate lagged behind the formation of nitrite, but at the end of eight weeks, nitrite had attained a low value or disappeared entirely, with corresponding increases in nitrate. This behavior differs from that of the other calcareous soil, Salinas clay, in which nitrite attained high values and remained high where ammonium hydroxide and ammonium sulfate were applied.

The formation of considerable quantities of nitrite in the alkaline soils may be explained on the basis of the inhibitory effect of free ammonia on the actvities of the Nitrobacter species. Meyerhof (1916) observed that .001 $\mathrm{M}$ ammonia at $\mathrm{pH} 9.5$ gave a 70 per cent inhibition of oxygen uptake by Nitrobacter in solution culture. Since the two principal steps in nitrification involve, first, the formation of nitrite, $\mathrm{NH}_{4}^{+}+\frac{3}{2} \mathrm{O}_{2} \rightarrow \mathrm{NO}_{2}^{-}+2 \mathrm{H}^{+}+\mathrm{H}_{2} \mathrm{O}$, followed by oxidation of nitrite to nitrate, $\mathrm{NO}_{2}^{-}+\frac{1}{2} \mathrm{O}_{2} \rightarrow \mathrm{NO}_{3}^{-}$, inhibition of the second step will result in nitrite accumulation. The accumulation of nitrite following application of ammonium fertilizers under field conditions has been reported by Chapman and Liebig (1952), Fuller et al. (1950), and by Duisberg and Buehrer (1954). This is an important practical consideration in view of the possible toxic effects of nitrite on the growth of crop plants. Fortunately, the alkaline conditions which give rise to nitrite accumulation are those found to produce the minimum toxic effects (Bingham et al., 1954). However, these workers observed that substantial quantities of ammonium seemed to increase nitrite toxicity in solution culture.

The effects of high application levels of ammonium fertilizers on the three alkaline soils are shown in table 2. These data differ from those of table 1 in that large amounts of nitrite accumulated in several instances as a result of selective inhibition of the nitrite-oxidizing bacteria. This appears to be characteristic of the calcareous soils in which the $\mathrm{pH}$ remained alkaline in spite of the production of considerable acid resulting from nitrification. In these soils there were sizable decreases in ammonium-nitrogen not compensated for by corresponding increases in nitrite and nitrate, a result which may doubtless be attributed to volatilization losses.

pH Changes. Since ammonium ion is converted to nitrate ion during the nitrification process, the resulting changes in soil acidity from oxidation of ammonium fertilizers are of interest. These are shown in tables 3 to 5 . In the two well-buffered acid soils (table 3), a significant downward trend in $\mathrm{pH}$ was observed at all levels of application. The application of 400 and 800 ppm ammonium hydroxide to Sacramento clay made it temporarily alkaline, which accounts in part for the fact that fertilizer in this form was nitrified more rapidly than either ammonium sulfate or ammonium nitrate. Rather large $\mathrm{pH}$ changes took place in the poorly buffered Hanford soil (table 4), and the very high $\mathrm{pH}$ values resulting from adding $800 \mathrm{ppm}$ ammonium hydroxide explain the complete inhibition of nitrification shown in figure 5 . The initially alkaline Yolo loam was made acid by all treatments except $50 \mathrm{ppm}$ ammonium hydroxide, and its behavior was in general similar to 
that of the acid soils. In the two calcareous soils (table 5) $\mathrm{pH}$ changes were fairly small, although the addition of ammonium hydroxide in large amounts produced rather high values temporarily. These results do not confirm the existence of a threshold $\mathrm{pH}$ of 7.6 to 7.8 for the second step in nitrification as reported by Caster et al. (1942). Fuller et al. (1950) have previously noted the formation of nitrates above a $\mathrm{pH}$ of $7.7 \pm 0.1$. In the present

TABLE 2

RELATIVE INHIBITORY EFFECT ON NITRIFICATION OF HIGH AMMONIUM FERTILIZER CONCENTRATIONS IN THREE ALKALINE SOILS

(Observations made at end of four weeks)

\begin{tabular}{|c|c|c|c|c|c|c|c|}
\hline Soil & Source of N & $\mathrm{N}$ added & Final $\mathrm{pH}$ & $\mathrm{NH}_{4}-\mathrm{N}$ & $\mathrm{NO}_{2}-\mathrm{N}$ & $\begin{array}{l}\text { Increase } \\
\text { in } \mathrm{NO}_{3}-\mathrm{N}\end{array}$ & $\begin{array}{c}\text { Per cent } \\
\text { of maximum } \\
\begin{array}{c}\text { nitrification } \\
\text { rate* }^{*}\end{array}\end{array}$ \\
\hline \multirow{3}{*}{ Yolo loam } & $\mathrm{NH}_{4} \mathrm{OH}$ & $\begin{array}{l}p p m \\
1,600 \\
3,200\end{array}$ & $\begin{array}{l}8.81 \\
9.04\end{array}$ & $\begin{array}{l}p p m \\
1,378 \\
2,180\end{array}$ & $\begin{array}{r}p p m \\
21 \\
0\end{array}$ & $\begin{array}{c}p p m \\
0 \\
0\end{array}$ & $\begin{array}{l}0 \\
0\end{array}$ \\
\hline & $\left(\mathrm{NH}_{4}\right)_{2} \mathrm{SO}_{4}$ & $\begin{array}{r}800 \\
1,600 \\
3,200\end{array}$ & $\begin{array}{l}5.37 \\
5.62 \\
6.25\end{array}$ & $\begin{array}{r}500 \\
889 \\
2,989\end{array}$ & $\begin{array}{l}0 \\
0 \\
0\end{array}$ & $\begin{array}{r}247 \\
69 \\
0\end{array}$ & $\begin{array}{r}44 \\
12 \\
0\end{array}$ \\
\hline & $\mathrm{NH}_{4} \mathrm{NO}_{3}$ & $\begin{array}{r}800 \\
1,600\end{array}$ & $\begin{array}{l}5.97 \\
6.39\end{array}$ & $\begin{array}{r}650 \\
1,490\end{array}$ & $\begin{array}{l}0 \\
0\end{array}$ & $\begin{array}{r}41 \\
0\end{array}$ & $\begin{array}{r}19 \\
0\end{array}$ \\
\hline \multirow{3}{*}{ Imperial clay } & $\mathrm{NH}_{4} \mathrm{OH}$ & $\begin{array}{r}800 \\
1,600 \\
3,200\end{array}$ & $\begin{array}{l}7.64 \\
8.57 \\
8.65\end{array}$ & $\begin{array}{r}174 \\
1,114 \\
1,439\end{array}$ & $\begin{array}{l}474 \\
\text { tr. } \\
0\end{array}$ & $\begin{array}{r}28 \\
0 \\
0\end{array}$ & $\begin{array}{l}3 \\
\mathbf{0} \\
\mathbf{0}\end{array}$ \\
\hline & $\left(\mathrm{NH}_{4}\right)_{2} \mathrm{SO}_{4}$ & $\begin{array}{r}800 \\
1,600 \\
3,200\end{array}$ & $\begin{array}{l}7.57 \\
7.48 \\
7.79\end{array}$ & $\begin{array}{r}14 \\
690 \\
2,748\end{array}$ & $\begin{array}{r}624 \\
702 \\
67\end{array}$ & $\begin{array}{r}129 \\
53 \\
0\end{array}$ & $\begin{array}{r}20 \\
4 \\
0\end{array}$ \\
\hline & $\mathrm{NH}_{4} \mathrm{NO}_{3}$ & 1,600 & 7.58 & 1,365 & 4 & 0 & 0 \\
\hline \multirow{3}{*}{ Salinas clay } & $\mathrm{NH}_{4} \mathrm{OH}$ & $\begin{array}{r}800 \\
1,600\end{array}$ & $\begin{array}{l}7.53 \\
8.76\end{array}$ & $\begin{array}{r}35 \\
689\end{array}$ & $\begin{array}{r}505 \\
11\end{array}$ & $\begin{array}{r}149 \\
4\end{array}$ & $\begin{array}{l}16 \\
<1\end{array}$ \\
\hline & $\left(\mathrm{NH}_{4}\right)_{2} \mathrm{SO}_{4}$ & $\begin{array}{r}800 \\
1,600 \\
3,200\end{array}$ & $\begin{array}{l}7.68 \\
7.09 \\
7.63\end{array}$ & $\begin{array}{r}11 \\
377 \\
2,157\end{array}$ & $\begin{array}{l}493 \\
847 \\
864\end{array}$ & $\begin{array}{r}180 \\
112 \\
0\end{array}$ & $\begin{array}{r}15 \\
9 \\
0\end{array}$ \\
\hline & $\mathrm{NH}_{4} \mathrm{NO}_{3}$ & $\begin{array}{l}1,600 \\
3,200\end{array}$ & $\begin{array}{l}7.38 \\
7.50\end{array}$ & $\begin{array}{l}1,113 \\
2,745\end{array}$ & $\begin{array}{r}251 \\
3\end{array}$ & $\begin{array}{l}0 \\
0\end{array}$ & $\begin{array}{l}0 \\
0\end{array}$ \\
\hline
\end{tabular}

* Maximum rate taken as highest rate observed for a given fertilizer in figures 6 to 10 .

experiments, the most pronounced effect of $\mathrm{pH}$ on the nitrification process appears to be on the acid side of neutrality, where the oxidation of ammonium ion became quite slow in the vicinity of $\mathrm{pH} 5.0$. In one experiment. where the Hanford sandy loam received $800 \mathrm{ppm}$ ammonium hydroxide, the $\mathrm{pH}$ remained above 9.0 for four weeks, and measurable nitrification did not begin until after the sixth week. In this latter instance, the nitrifying bacteria were undoubtedly affected by the high ammonium concentration associated with the high $\mathrm{pH}$, so that inhibition cannot be attributed to high $\mathrm{pH}$ alone. 
TABLE 3

pH VALUES OF TWO WELL BUFFERED, ACID SOILS DURING NITRIFICATION

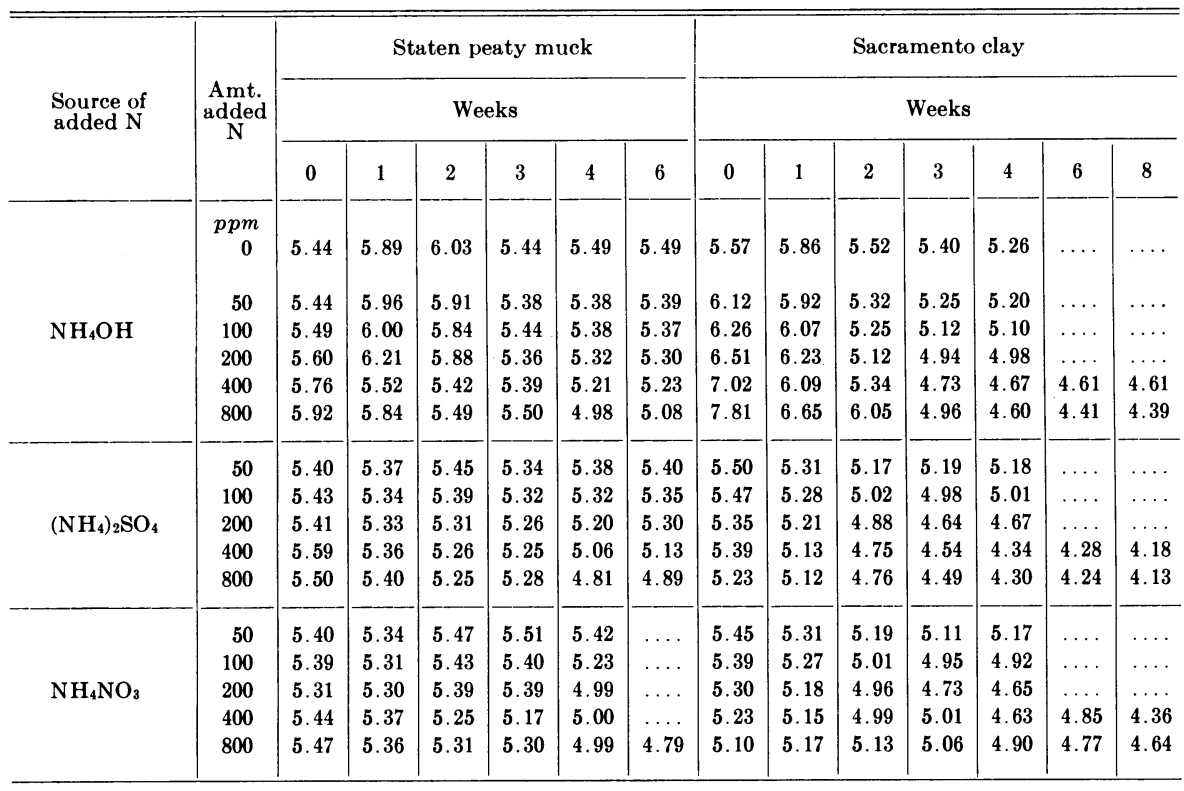

TABLE 4

pH VALUES OF A POORLY BUFFERED, SLIGHTLY ACID SOIL AND A FAIRLY WELL-BUFFERED, SLIGHTLY ALKALINE SOIL DURING NITRIFICATION

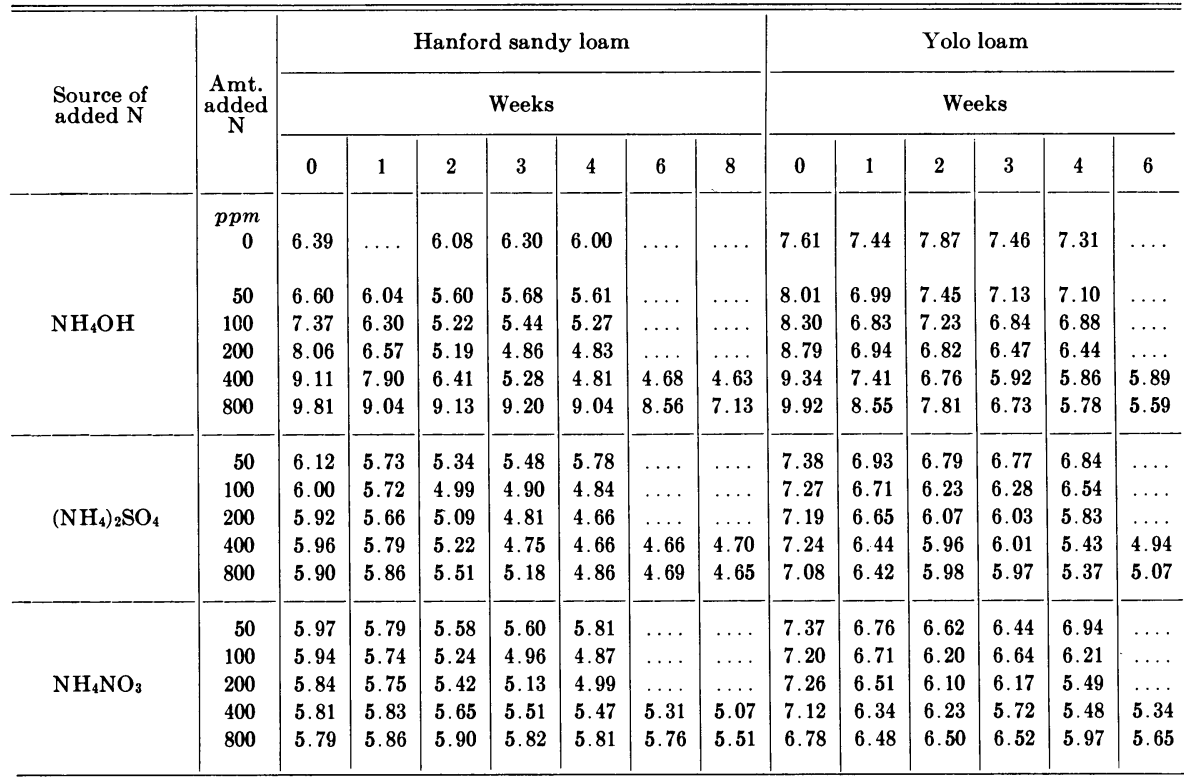




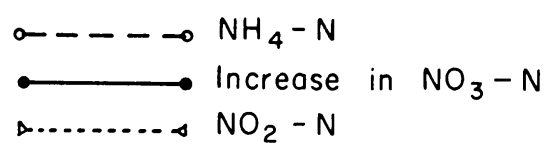

$\mathrm{NH}_{4} \mathrm{OH}$

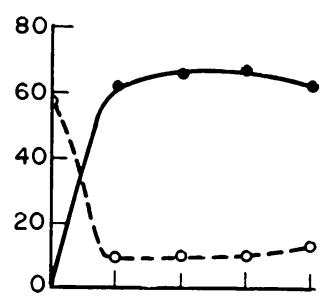

$E$
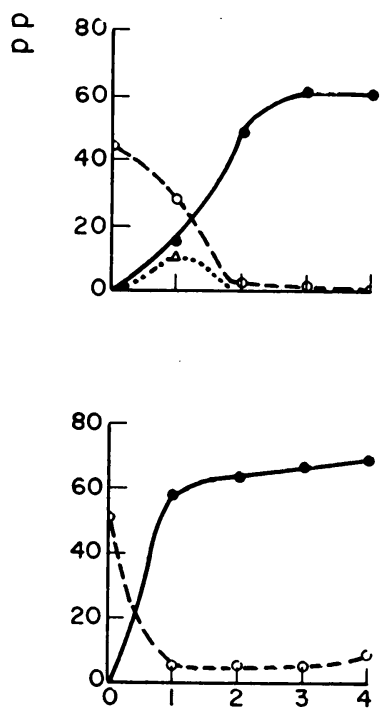

$\left(\mathrm{NH}_{4}\right)_{2} \mathrm{SO}_{4}$

YOLO LOAM
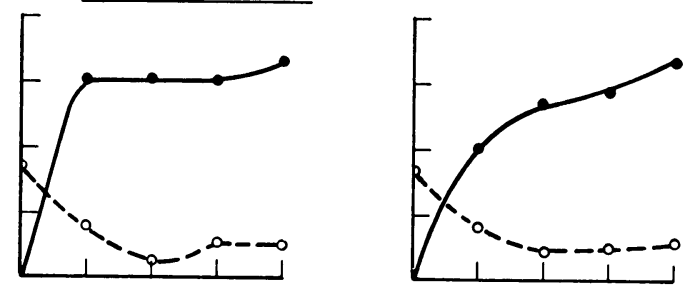

\section{IMPERIAL CLAY}
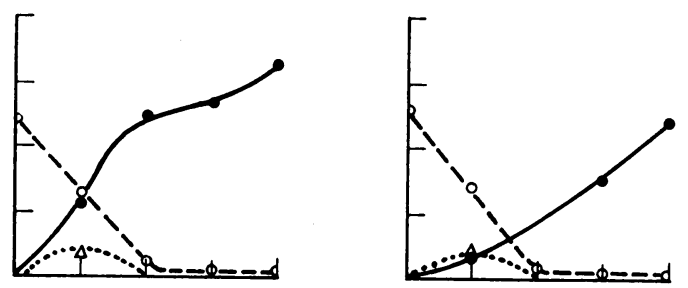

SALINAS CLAY
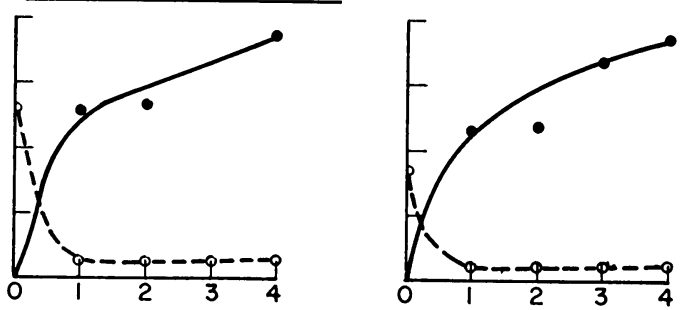

WEEKS

Fig. 6. Inorganic nitrogen ehanges in three alkaline soils receiving $50 \mathrm{ppm}$ ammonium nitrogen.

Comparison of Nitrification Rates. It is apparent in figures 1 to 10 that the three types of ammonium fertilizers did not nitrify at the same rate. Table 6 shows the time (in weeks) required for the formation of an amount of nitrate equivalent to half the added ammonium nitrogen. No particular significance is attached to this "half-life" except that it serves as a convenient 

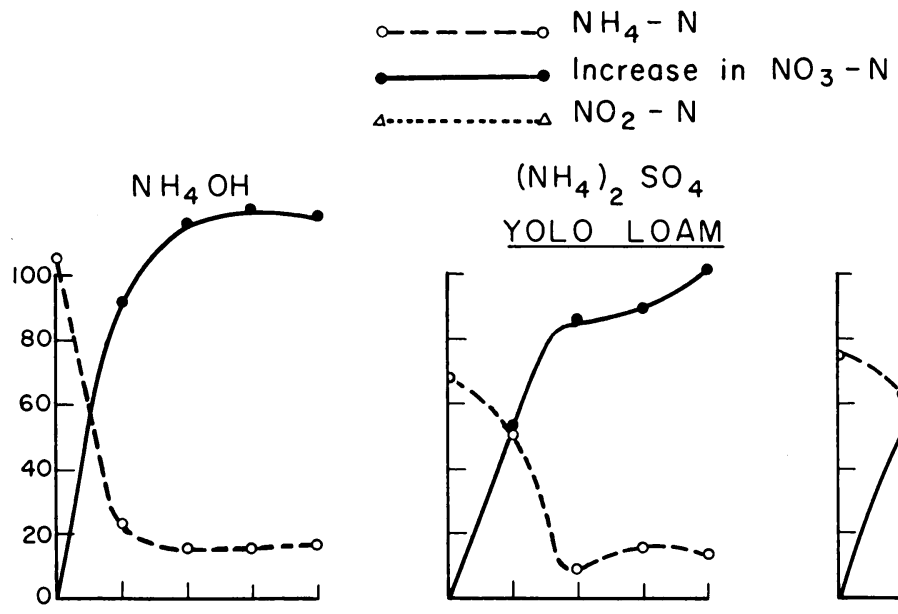

$\left(\mathrm{NH}_{4}\right)_{2} \mathrm{SO}_{4}$

$\mathrm{NH}_{4} \mathrm{NO}_{3}$

YOLO LOAM
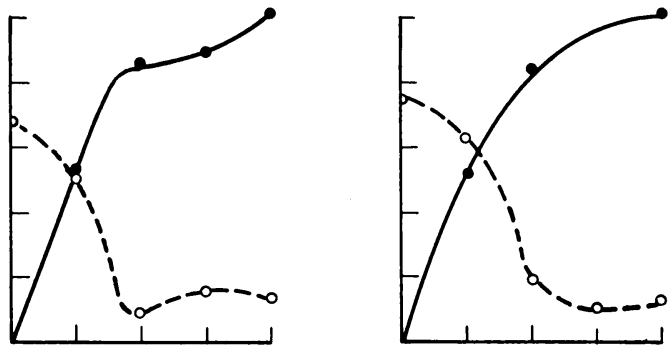

IMPERIAL CLAY
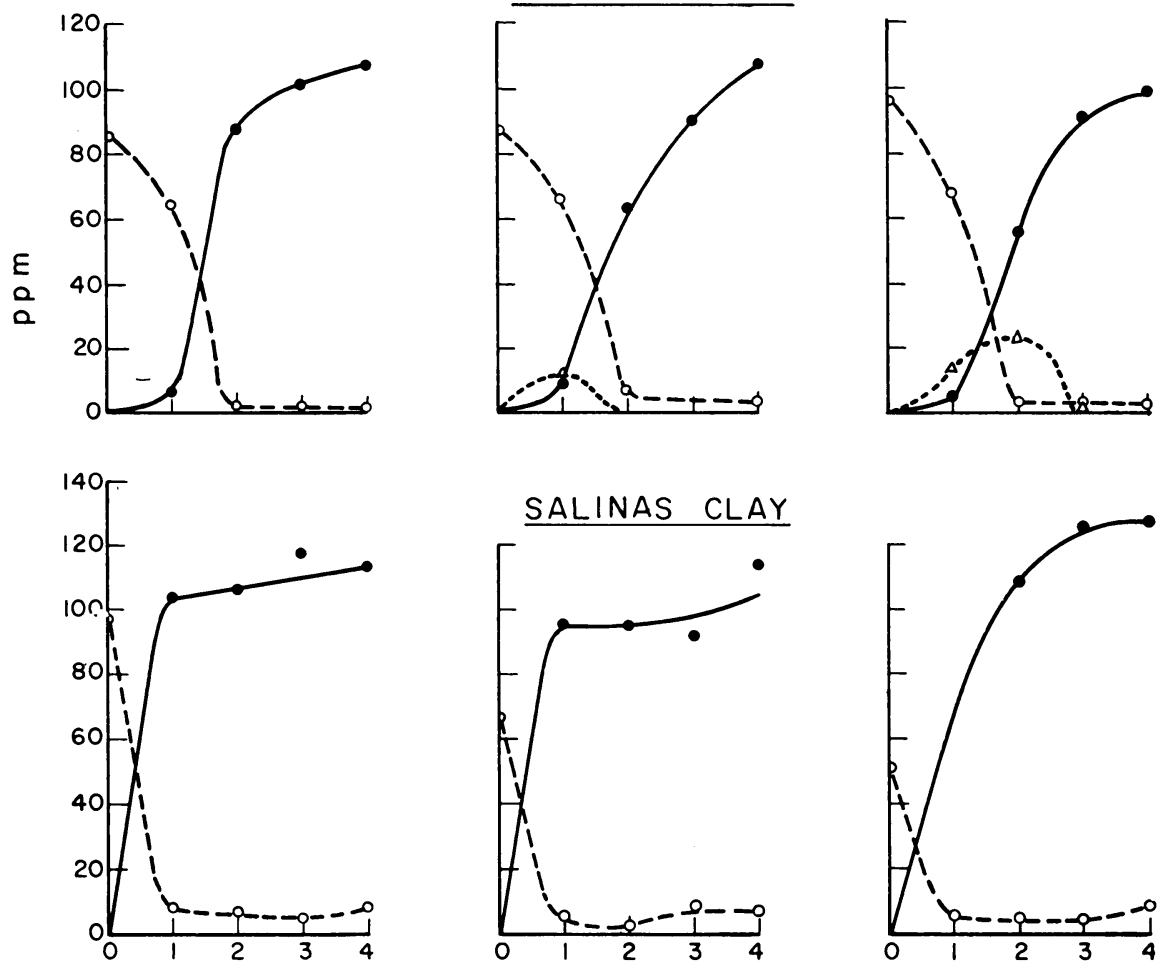

WEEKS

Fig. 7. Inorganic nitrogen changes in three alkaline soils receiving $100 \mathrm{ppm}$ ammonium nitrogen. 
TABLE 5

pH VALUES OF TWO ALKALINE CAICAREOUS SOILS DURING NITRIFICATION

\begin{tabular}{|c|c|c|c|c|c|c|c|c|c|c|c|c|c|c|c|}
\hline \multirow{3}{*}{$\begin{array}{c}\text { Source } \\
\text { of added } \\
\mathrm{N}\end{array}$} & \multirow{3}{*}{$\begin{array}{l}\text { Amt. } \\
\text { added } \\
\mathrm{N}\end{array}$} & \multicolumn{7}{|c|}{ Salinas clay } & \multicolumn{7}{|c|}{ Imperial clay } \\
\hline & & \multicolumn{7}{|c|}{ Weeks } & \multicolumn{7}{|c|}{ Weeks } \\
\hline & & 0 & 1 & 2 & 3 & 4 & 6 & 8 & 0 & 1 & 2 & 3 & 4 & 6 & 8 \\
\hline \multirow{6}{*}{$\mathrm{NH}_{4} \mathrm{OH}$} & $\begin{array}{c}p p m \\
0\end{array}$ & 8.10 & 7.97 & 8.17 & 8.11 & 8.18 & $\cdots$ & 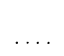 & 8.00 & 7.95 & 8.10 & 7.90 & 8.08 & 8.04 & 8.07 \\
\hline & 50 & 8.54 & 7.89 & 8.08 & 8.11 & 8.04 & $\ldots$ & 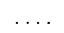 & 8.40 & 7.96 & 7.86 & 7.93 & 8.07 & 8.03 & 8.07 \\
\hline & 100 & 8.81 & 7.88 & 8.01 & 8.11 & 7.98 & & & 8.61 & 8.00 & 7.90 & 7.88 & 7.99 & 8.02 & 8.02 \\
\hline & 200 & 9.20 & 7.74 & 7.90 & 7.94 & 7.88 & & & 8.92 & 8.10 & 7.87 & 7.85 & 7.94 & 8.01 & 7.98 \\
\hline & 400 & 9.37 & 7.44 & 7.76 & 7.86 & 7.75 & $\ldots$ & $\ldots$ & 9.20 & 8.33 & 7.53 & 7.82 & 7.88 & 7.91 & 7.96 \\
\hline & 800 & 9.90 & 8.64 & 7.44 & 7.54 & 7.53 & 7.59 & 7.63 & 9.54 & 8.65 & 8.38 & 8.01 & 7.64 & 7.90 & 7.90 \\
\hline \multirow{5}{*}{$\left(\mathrm{NH}_{4}\right)_{2} \mathrm{SO}_{4}$} & 50 & 8.04 & 8.04 & 7.88 & 7.94 & 8.10 & & & 7.99 & 7.73 & 7.90 & 7.85 & 7.90 & 7.90 & 7.93 \\
\hline & 100 & 8.10 & 7.92 & 7.89 & 7.78 & 8.02 & $\ldots$ & $\ldots$ & 8.00 & 7.69 & 7.90 & 7.81 & 7.90 & 7.87 & 7.93 \\
\hline & 200 & 8.00 & 7.82 & 7.76 & 7.69 & 7.95 & $\ldots$ & $\ldots$ & 7.98 & 7.73 & 7.71 & 7.63 & 7.83 & 7.73 & 7.83 \\
\hline & 400 & 7.91 & 7.47 & 7.62 & 7.67 & 7.79 & & & 7.95 & 7.73 & 7.48 & 7.55 & 7.77 & 7.69 & 7.75 \\
\hline & 800 & 7.76 & 7.35 & 7.28 & 7.41 & 7.68 & 7.53 & $8.13^{\circ}$ & 7.90 & 7.61 & 7.29 & 7.26 & 7.57 & 7.51 & 7.71 \\
\hline \multirow{5}{*}{$\mathrm{NH}_{4} \mathrm{NO}_{3}$} & 50 & 8.08 & 7.94 & 7.70 & 7.80 & 8.01 & $\ldots$ & 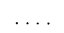 & 7.96 & 7.78 & 7.79 & 7.90 & 7.88 & 7.90 & 7.91 \\
\hline & 100 & 8.02 & 7.81 & 7.71 & 7.79 & 7.65 & & & 7.93 & 7.77 & 7.72 & 7.90 & 7.85 & 7.93 & 8.00 \\
\hline & 200 & 8.03 & 7.60 & 7.60 & 7.71 & 7.65 & $\ldots$ & & 7.86 & 7.85 & 7.53 & 7.83 & 7.77 & 7.85 & 7.87 \\
\hline & 400 & 7.80 & 7.25 & 7.49 & 7.52 & 7.36 & & & 7.82 & 7.80 & 7.51 & 7.60 & 7.67 & 7.76 & 7.74 \\
\hline & 800 & 7.65 & 7.54 & 6.96 & 7.20 & 7.27 & 7.39 & 7.43 & 7.75 & 7.71 & 7.61 & 7.47 & 7.21 & 7.56 & 7.66 \\
\hline
\end{tabular}

TABLE 6

WEEKS REQUIRED FOR FORMATION OF NITRATE EQUIVALENT TO HALF THE ADDED AMMONIUM NITROGEN

\begin{tabular}{|c|c|c|c|c|c|c|c|c|c|}
\hline \multicolumn{10}{|c|}{ Soil } \\
\hline \multirow{3}{*}{ Rate } & \multicolumn{3}{|c|}{ Staten } & \multicolumn{3}{|c|}{ Hanford } & \multicolumn{3}{|c|}{ Sacramento } \\
\hline & \multicolumn{3}{|c|}{ Form of added $N$} & \multicolumn{3}{|c|}{ Form of added $\mathrm{N}$} & \multicolumn{3}{|c|}{ Form of added $\mathrm{N}$} \\
\hline & $\mathrm{NH}_{4} \mathrm{OH}$ & $\left(\mathrm{NH}_{4}\right)_{2} \mathrm{SO}_{4}$ & $\mathrm{NH}_{4} \mathrm{NO}_{3}$ & $\mathrm{NH}_{4} \mathrm{OH}$ & $\left(\mathrm{NH}_{4}\right)_{2} \mathrm{SO}_{4}$ & $\mathrm{NH}_{4} \mathrm{NO}_{3}$ & $\mathrm{NH}_{4} \mathrm{OH}$ & $\left(\mathrm{NH}_{4}\right)_{2} \mathrm{SO}_{4}$ & $\mathrm{NH}_{4} \mathrm{NO}_{3}$ \\
\hline $\begin{array}{c}p p m \\
50 \ldots \ldots\end{array}$ & 0.5 & 0.6 & 0.3 & 0.8 & 1.0 & 1.1 & 0.2 & 0.4 & 0.8 \\
\hline $100 \ldots \ldots$ & 0.3 & 0.8 & 1.5 & 1.1 & 1.4 & 2.2 & 0.6 & 0.8 & 1.4 \\
\hline $200 \ldots \ldots$ & 1.2 & 1.4 & $>4$ & 1.7 & 3.0 & $>4$ & 1.1 & 1.8 & 2.2 \\
\hline $400 \ldots \ldots$ & 1.4 & 1.3 & 2.5 & 2.4 & $>6$ & $>>6$ & 1.9 & 2.1 & 7.0 \\
\hline \multirow[t]{2}{*}{800 . } & 2.2 & 2.7 & 4.5 & $>8$ & $>8$ & $>>8$ & 3.0 & $>8$ & $>8$ \\
\hline & \multicolumn{3}{|c|}{ Yolo } & \multicolumn{3}{|c|}{ Imperial } & \multicolumn{3}{|c|}{ Salinas } \\
\hline 50. & 0.3 & 0.4 & 0.5 & 1.3 & 1.1 & 2.6 & 0.5 & 0.4 & 0.4 \\
\hline 100 . & 0.4 & 1.0 & 1.0 & 1.5 & 1.7 & 1.9 & 0.4 & 0.4 & 0.7 \\
\hline $200 \ldots \ldots$ & 0.8 & 1.9 & 2.1 & 1.6 & 2.2 & 2.2 & 0.5 & 0.5 & 0.5 \\
\hline $400 \ldots$ & 1.6 & 3.4 & 5.0 & 3.5 & 2.1 & 2.6 & 1.3 & 0.6 & 0.7 \\
\hline $800 \ldots \ldots$ & 3.6 & $>6$ & $>>6$ & 8.0 & 5.0 & 3.8 & $>6$ & $>6$ & 1.7 \\
\hline
\end{tabular}




$$
\begin{array}{ll}
\circ-\ldots-\cdots & \mathrm{NH}_{4}-\mathrm{N} \\
\bullet & \text { Increase in } \mathrm{NO}_{3}-\mathrm{N} \\
\triangle \cdots \ldots \ldots . . & \mathrm{NO}_{2}-\mathrm{N}
\end{array}
$$

$\mathrm{NH}_{4} \mathrm{OH}$
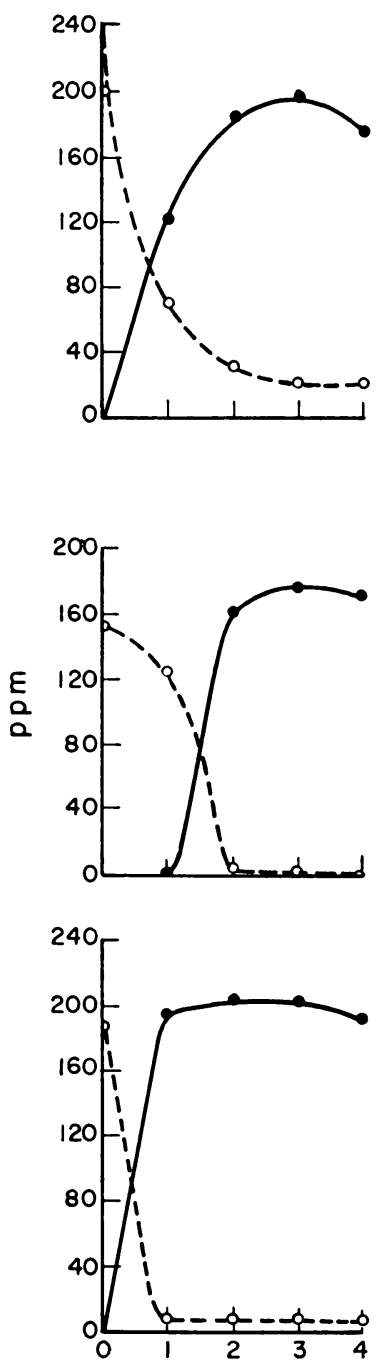

$\left(\mathrm{NH}_{4}\right)_{2} \mathrm{SO}_{4}$

$\mathrm{NH}_{4} \mathrm{NO}_{3}$
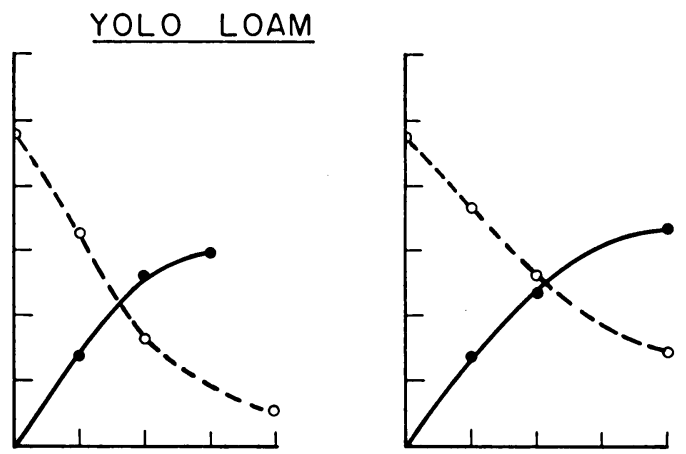

IMPERIAL CLAY
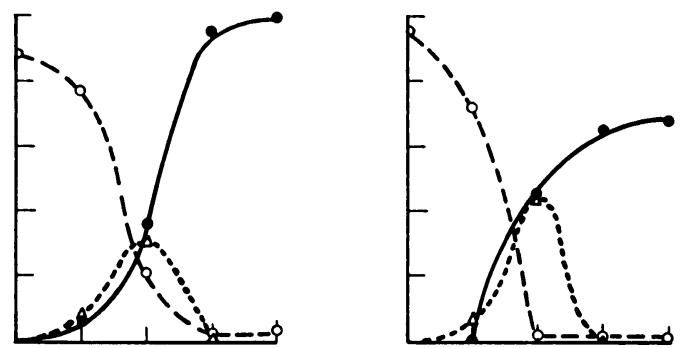

SALINAS CLAY
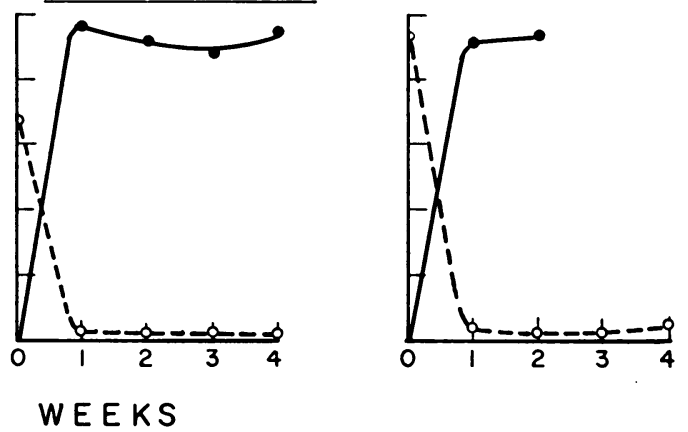

WEEKS

Fig. 8. Inorganic nitrogen changes in three alkaline soils receiving $200 \mathrm{ppm}$ ammonium nitrogen. 


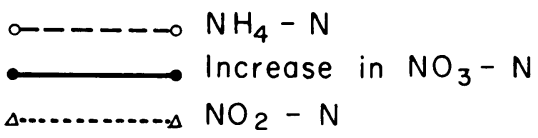

$\mathrm{NH}_{4} \mathrm{OH}$

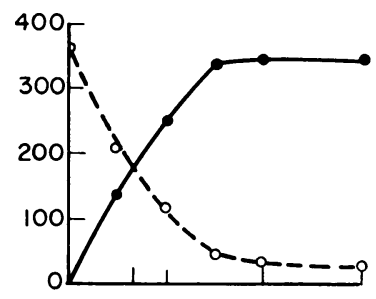

$\left(\mathrm{NH}_{4}\right)_{2} \mathrm{SO}_{4}$

$\mathrm{NH}_{4} \mathrm{NO}_{3}$

YOLO LOAM
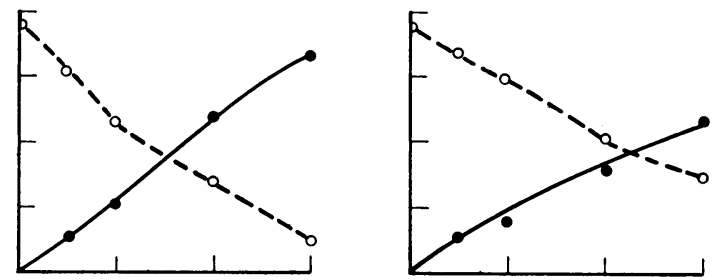

IMPERIAL CLAY
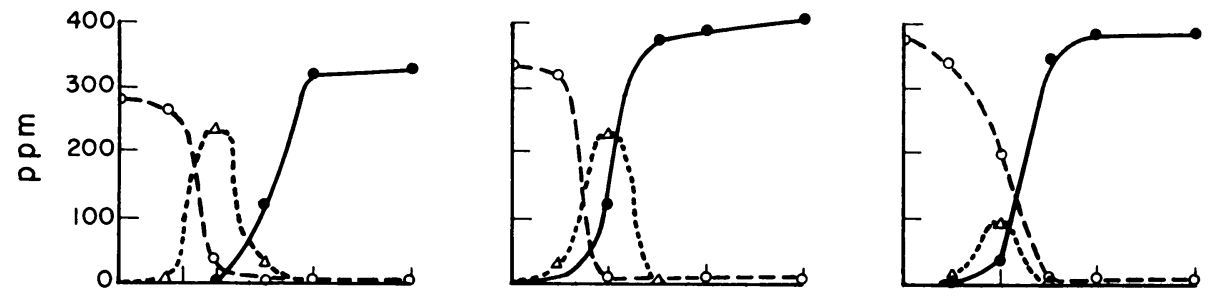

\section{SALINAS CLAY}
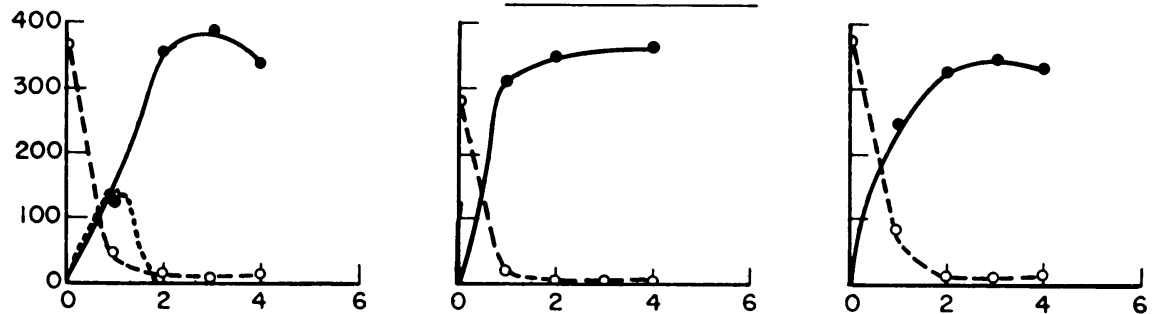

WEEKS

Fig. 9. Inorganic nitrogen changes in three alkaline soils receiving $400 \mathrm{ppm}$ ammonium nitrogen.

basis of comparison. Considering the three acid soils and the noncalcareous alkaline Yolo soil, rates of nitrification followed the order $\mathrm{NH}_{4} \mathrm{OH}>$ $\left(\mathrm{NH}_{4}\right)_{2} \mathrm{SO}_{4}>\mathrm{NH}_{4} \mathrm{NO}_{3}$ with but one exception.

With respect to the two calcareous soils, no such generalization can be made. In these there was a tendency, at the higher rates, for ammonium 


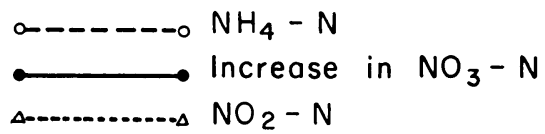

$\mathrm{NH}_{4} \mathrm{OH}$

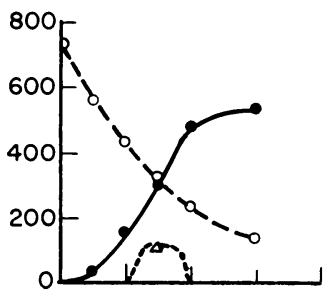

$\left(\mathrm{NH}_{4}\right)_{2} \mathrm{SO}_{4}$

YOLO LOAM
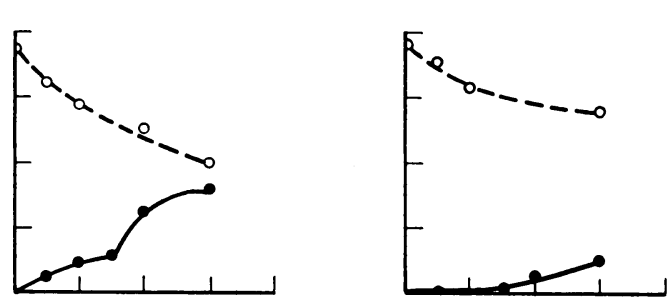

IMPERIAL CLAY
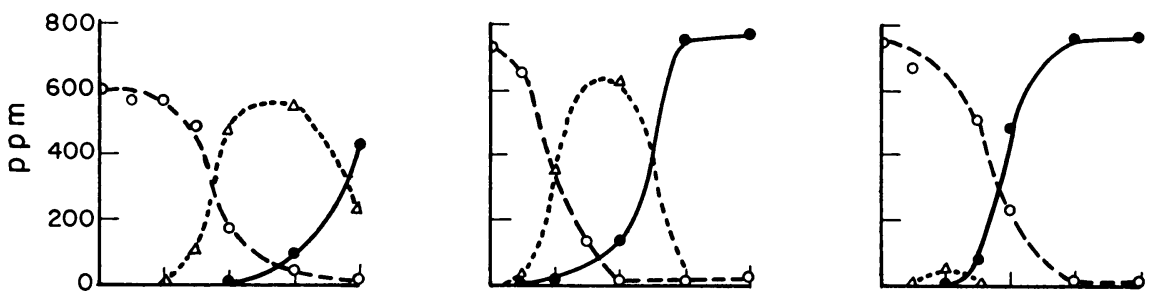

SALINAS CLAY

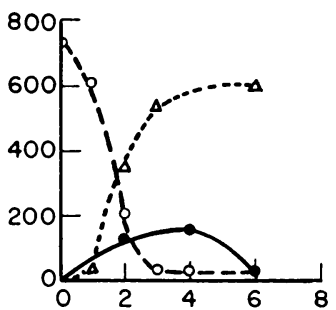

$\mathrm{NH}_{4} \mathrm{NO}_{3}$

\section{Y}

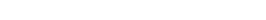

. 
TABLE 7

COMPARISON OF MAXIMUM NITRIFICATION RATES OF THREE AMMONIUM FERTILIZERS IN ACID SOILS

\begin{tabular}{|c|c|c|c|c|c|c|c|}
\hline \multirow{2}{*}{$\begin{array}{l}\text { Nitrogen } \\
\text { source }\end{array}$} & \multirow{2}{*}{$\begin{array}{r}\mathrm{NH}_{4}-\mathrm{N} \\
\text { added }\end{array}$} & \multicolumn{2}{|c|}{ Staten peaty muck } & \multicolumn{2}{|c|}{ Sacramento clay } & \multicolumn{2}{|c|}{ Hanford sandy loam } \\
\hline & & $\begin{array}{l}\text { Period of } \\
\text { max. rate }\end{array}$ & Max. rate & $\begin{array}{l}\text { Period of } \\
\text { max. rate }\end{array}$ & Max. rate & $\begin{array}{l}\text { Period of } \\
\text { max. rate }\end{array}$ & Max. rate \\
\hline \multirow{6}{*}{$\mathrm{NH}_{4} \mathrm{OH}$} & $p p m$ & weeks & $p p m / d a y$ & weeks & $p p m / d a y$ & weeks & $p p m / d a y$ \\
\hline & 50 & $0-1$ & 7.7 & $0-1$ & 11.0 & $0-1$ & 5.1 \\
\hline & 100 & $0-2$ & 13.0 & $0-1$ & 11.1 & $1-2$ & 8.1 \\
\hline & 200 & $1-2$ & 20.4 & $0-1$ & 12.3 & $1-2$ & 12.7 \\
\hline & 400 & $0-1$ & 21.0 & $0-1$ & 14.6 & $1-2$ & 17.4 \\
\hline & 800 & $2-4$ & 30.6 & $0-1$ & 14.3 & $6-8$ & $0.0^{*}$ \\
\hline \multirow{5}{*}{$\left(\mathrm{NH}_{4}\right)_{2} \mathrm{SO}_{4}$} & 50 & $0-1$ & 6.4 & $0-1$ & 9.1 & $1-2$ & 5.0 \\
\hline & 100 & $1-2$ & 10.1 & $0-1$ & 11.4 & $1-9$ & 7.6 \\
\hline & 200 & $1-2$ & 19.6 & $2-3$ & 11.1 & $1-2$ & 6.4 \\
\hline & 400 & $0-1$ & 20.6 & $2-3$ & 19.3 & $2-3$ & 9.1 \\
\hline & 800 & $2-4$ & 27.0 & $2-3$ & 16.3 & $2-3$ & 4.7 \\
\hline \multirow{5}{*}{$\mathrm{NH}_{4} \mathrm{NO}_{3}$} & 50 & $0-2$ & 6.4 & $0-1$ & 5.0 & $0-1$ & 2.9 \\
\hline & 100 & $2-3$ & 13.6 & $1-2$ & 7.9 & $3-4$ & 4.6 \\
\hline & 200 & $2-3$ & $\ldots$ & $2-3$ & 14.0 & $2-3$ & 3.9 \\
\hline & 400 & $2-3$ & 20.3 & $2-4$ & 9.2 & $0-1$ & 1.0 \\
\hline & 800 & $4-6$ & 22.4 & $6-8$ & 12.1 & $>8$ & $\ldots$ \\
\hline
\end{tabular}

* Some nitrite produced.

TABLE. 8

COMPARISON OF MAXIMUM NITRIFICATION RATES OF THREE AMMONIUM FERTILIZERS IN ALKALINE SOILS

\begin{tabular}{|c|c|c|c|c|c|c|c|}
\hline \multirow{2}{*}{$\begin{array}{l}\text { Nitrogen } \\
\text { source }\end{array}$} & \multirow{2}{*}{$\begin{array}{c}\mathrm{NH}_{4}-\mathrm{N} \\
\text { added }\end{array}$} & \multicolumn{2}{|c|}{ Yolo loam } & \multicolumn{2}{|c|}{ Imperial clay } & \multicolumn{2}{|c|}{ Salinas clay } \\
\hline & & $\begin{array}{l}\text { Period of } \\
\text { max. rate }\end{array}$ & Max. rate & $\begin{array}{l}\text { Period of } \\
\text { max. rate }\end{array}$ & Max. rate & $\begin{array}{l}\text { Period of } \\
\text { max. rate }\end{array}$ & Max. rate \\
\hline $\mathrm{NH}_{4} \mathrm{OH}$ & $\begin{array}{r}p p m \\
50 \\
100 \\
200 \\
400 \\
800\end{array}$ & $\begin{array}{c}\text { weeks } \\
0-1 \\
0-1 \\
0-1 \\
0-1 \\
2-3\end{array}$ & $\begin{array}{c}p p m / d a y \\
8.9 \\
13.0 \\
17.1 \\
19.3 \\
17.8\end{array}$ & $\begin{array}{c}\text { weeks } \\
1-2 \\
1-2 \\
1-2 \\
3-4 \\
6-8\end{array}$ & $\begin{array}{c}p p m / d a y \\
7.4 \\
11.6 \\
22.9 \\
28.6 \\
27.6\end{array}$ & $\begin{array}{c}\text { weeks } \\
0-1 \\
0-1 \\
0-1 \\
1-2 \\
1-2\end{array}$ & $\begin{array}{c}p p m / d a y \\
8.3 \\
14.7 \\
27.7 \\
32.4 \\
18.9\end{array}$ \\
\hline$\left(\mathrm{NH}_{4}\right)_{2} \mathrm{SO}_{4}$ & $\begin{array}{r}50 \\
100 \\
200 \\
400 \\
800\end{array}$ & $\begin{array}{l}0-1 \\
0-1 \\
3-4 \\
3-4 \\
3-4\end{array}$ & $\begin{array}{r}7.1 \\
7.4 \\
10.0 \\
19.3 \\
20.0\end{array}$ & $\begin{array}{l}1-2 \\
1-2 \\
2-3 \\
2-3 \\
4-6\end{array}$ & $\begin{array}{r}3.7 \\
7.6 \\
17.1 \\
38.9 \\
44.5\end{array}$ & $\begin{array}{l}0-1 \\
0-1 \\
0-1 \\
0-1 \\
0-1\end{array}$ & $\begin{array}{r}7.4 \\
13.6 \\
26.9 \\
44.0 \\
22.6\end{array}$ \\
\hline $\mathrm{NH}_{4} \mathrm{NO}_{3}$ & $\begin{array}{r}50 \\
100 \\
200 \\
400 \\
800\end{array}$ & $\begin{array}{l}0-1 \\
0-1 \\
0-1 \\
0-1 \\
3-4\end{array}$ & $\begin{array}{l}5.7 \\
7.4 \\
7.7 \\
7.3 \\
4.1\end{array}$ & $\begin{array}{l}3-4 \\
1-2 \\
1-2 \\
2-3 \\
3-4\end{array}$ & $\begin{array}{r}4.0 \\
7.0 \\
14.6 \\
43.9 \\
42.4\end{array}$ & $\begin{array}{l}0-1 \\
0-2 \\
0-1 \\
0-1 \\
1-2\end{array}$ & $\begin{array}{r}6.6 \\
9.9 \\
\ldots \\
35.6 \\
54.9\end{array}$ \\
\hline
\end{tabular}

The reasons for slower oxidation of ammonium nitrate than of ammonium sulfate in acid soils are less obvious, but may be due to a salt concentration effect, particularly at the higher application levels. In this connection it 
should be pointed out that, in all experiments reported here, the three fertilizers were compared on an equivalent ammonium-nitrogen basis, whereas in a field situation the nitrate portion of the ammonium nitrate would be taken into consideration. From a practical standpoint, the slower nitrification of ammonium nitrogen in ammonium nitrate assumes slight importance, since only half the nitrogen of the compound is involved.

Comparisons of maximum nitrification rates and the period during which they were attained are shown in tables 7 and 8 . A general, though not invariable, observation is that as the level of added ammonium nitrogen increased, the period of maximum nitrification rate tended to come later in the course of the incubation. The maximum rates attained emphasize the capacity of the nitrifying flora in most of these soils to convert large quantities of ammonium nitrogen to nitrate in relatively short time. For example, rates above 40 ppm per day were observed in the two calcareous soils, Salinas clay and Imperial clay. The highest nitrification rate reported by Frederick (1956) was 91 p.pm per week, or $13 \mathrm{ppm}$ per day, which occurred in a Genesee silt loam, $\mathrm{pH} 7.7$, incubated at $35^{\circ} \mathrm{C}$.

\section{DISCUSSION AND CONCLUSIONS}

Nitrifying bacteria in the soil are seldom, if ever, confronted with a situation in which their substrate, the ammonium ion, is uniformly distributed throughout their environment. Because of the nature of fertilizer application practices and the tendency of the ammonium ion as well as of free ammonia to be absorbed at the point of contact with soil colloids, localized high concentrations are the rule rather than the exception. Invariably a concentration gradient is produced, with a maximum at the point or line of application. The distribution of ammonium nitrogen around this maximum depends on several factors, including type of fertilizer, depth of application, soil texture, and soil moisture. Lorenz et al. (1955) have shown that, in alkaline sandy soils, aqua ammonia and ammonia gas form a more diffuse pattern than does ammonium sulfate, with much of the movement of the former two materials being in an upward direction.

If the results of these experiments can be considered to represent a cross section of a fertilizer band, it can be said that, at the edge of the band where ammonium concentrations are low, nitrification occurs rapidly and completely. Higher ammonium concentrations near the center of the band may inhibit nitrification completely if the soil is poorly buffered although most soils in these experiments could still nitrify at relatively high concentrations of ammonium ion. In the case of aqueous and anhydrous ammonia, the tendency to produce high $\mathrm{pH}$ values, with resulting inhibition of nitrification in coarse-textured soils, may be partly compensated for by the more diffuse fertilizer band produced. Where inhibition of nitrification occurs following ammonium-fertilizer application, it may be due to one or more causes:

1. Excessively high $\mathrm{pH}$ resulting from application of alkaline materials. A maximal soil $\mathrm{pH}$ value for adequate nitrification is not suggested, since considerable variability among soils is evident in these experiments. Examination of tables 3 to 5 indicates nitrification occurring at $\mathrm{pH}$ values even above 9.0. 
2. Excessively low $\mathrm{pH}$ resulting from formation of nitrous and nitric acids. In localized zones, changes can be in excess of one $\mathrm{pH}$ unit even in heavy soils. Nitrification becomes quite slow below $\mathrm{pH} 5.0$, but may proceed at 4.5 or lower. Soil in the vicinity of a fertilizer band may thus become quite acid as a result of nitrification even though the main body of soil is unaffected.

3. Presence of free ammonia, exerting selective inhibition on the nitrateforming bacteria. Free ammonia, which is formed in greater quantity in alkaline soils, may result in nitrite accumulation in amounts toxic to plants. Acute conditions may further inhibit transformation of ammonium to nitrite.

4. Salt effect, resulting in osmotic concentrations too high for optimal activity of nitrifying bacteria. Specific ion toxicity of ions such as nitrate might possibly be involved in some instances where ammonium nitrate additions produced inhibitory effects.

It is difficult to state, in a particular case, just what factors have contributed to inhibition of the nitrifying bacteria, but it is possible to predict the conditions under which inhibition is likely to occur. For example, high concentrations of any type of ammonium fertilizer, coupled with a soil reaction on the alkaline side of neutrality, are likely to result in nitrite accumulation. The only instance of nitrite accumulation at a $\mathrm{pH}$ value below 7.0 observed in these experiments was in Sacramento clay at $\mathrm{pH} 6.9$ (tables 2 and 3 ). In calcareous soils the problem is aggravated.

One significant point emphasized by the data of these experiments is that, under optimum conditions, nitrification is an extraordinarily rapid process. This fact should prove helpful in interpreting numerous field observations involving either response or lack of response to ammonium fertilizers. If moisture, $\mathrm{pH}$, and temperature conditions of the soil are satisfactory, it may be assumed with confidence that nitrate will be produced from an added ammonium fertilizer in sufficient quantity to keep pace with the needs of growing plants in most agricultural soils. 


\section{LITERATURE CITED}

Bingham, F. T., H. D. Chapman, and A. L. Pugh

1954. Solution-culture studies of nitrite toxicity to plants. Soil Sei. Soc. Amer. Proc. $18: 305-8$.

BLUe, W. G., and C. F. ENo

1954. Distribution and retention of anhydrous ammonia in sandy soils. Soil Sci. Soc. Amer. Proc. 18:420-24.

Caster, A. B., W. P. Martin, and T. F. Buehrer

1942. The microbiological oxidation of ammonia in desert soil. 1. Threshold $\mathrm{pH}$ value for nitrification. Ariz. Agr. Exp. Sta. Tech. Bul. 96.

Chapman, H. D., and G. F. Liebig

1952. Field and laboratory studies of nitrite accumulation in soils. Soil Sci. Soc. Amer. Proc. $16: 276-82$.

DUisBerg, P. C., and T. F. Buehrer

1954. Effect of ammonia and its oxidation products on rate of nitrification and plant growth. Soil Sci. 78:37-49.

Eno, C. F., and W. G. BLuE

1954. The effect of anhydrous ammonia on nitrification and the microbiological population in sandy soils. Soil Sci. Soc. Amer. Proc. 18:178-81.

ENo, C. F., W. G. BLUE, and J. M. GooD

1955. The effect of anhydrous ammonia on nematodes, fungi, bacteria, and nitrification in some Florida soils. Soil Sci. Soc. Amer. Proc. 19:55-8.

FREDERICK, L. R.

1956. The formation of nitrate from ammonium nitrogen in soils: I. Effect of temperature. Soil Sci. Soc. Amer. Proc. $20: 496-500$.

Fuller, W. H., W. P. Martin, and W. T. MCGeorge

1950. Behavior of nitrogenous fertilizers in alkaline calcareous soils: II. Field experiments with organic and inorganic nitrogenous compounds. Ariz. Agr. Exp. Sta. Bul. 121.

LGReNz, O. A., J. C. BISHoP, and D. N. WRIGHT

1955. Liquid, dry, and gaseous fertilizers for onions on sandy loam soils. Proc. Amer. Soc. Hort. Sci. $65: 296-306$.

MEYERHOF, O.

1916. Untersuchungen über den Atmungsforgang nitrifizierender Bakterien. Pflügers Arch. ges. Physiol. $164: 352 ; 165: 229$.

SChloesing, T., and A. MÜNTZ

1877. Sur la nitrification par les ferments organisés. Compt. Rend Acad. Sci. Paris 84: 301. 

The journal Hilgardia is published at irregular intervals, in volumes of about 600 pages. The number of issues per volume varies.

Subscriptions are not sold. The periodical is sent as published only to libraries, or to institutions in foreign countries having publications to offer in exchange.

You may obtain a single copy of any issue free, as long as the supply lasts; please requdst by volume and issue number from:
Agricultural Publications
Room 22, Giannini Hall
University of California
Berkeley 4, California

The limit to nonresidents of California is 10 separate issues on a single order. A list of the issues still available will be sent on request. 


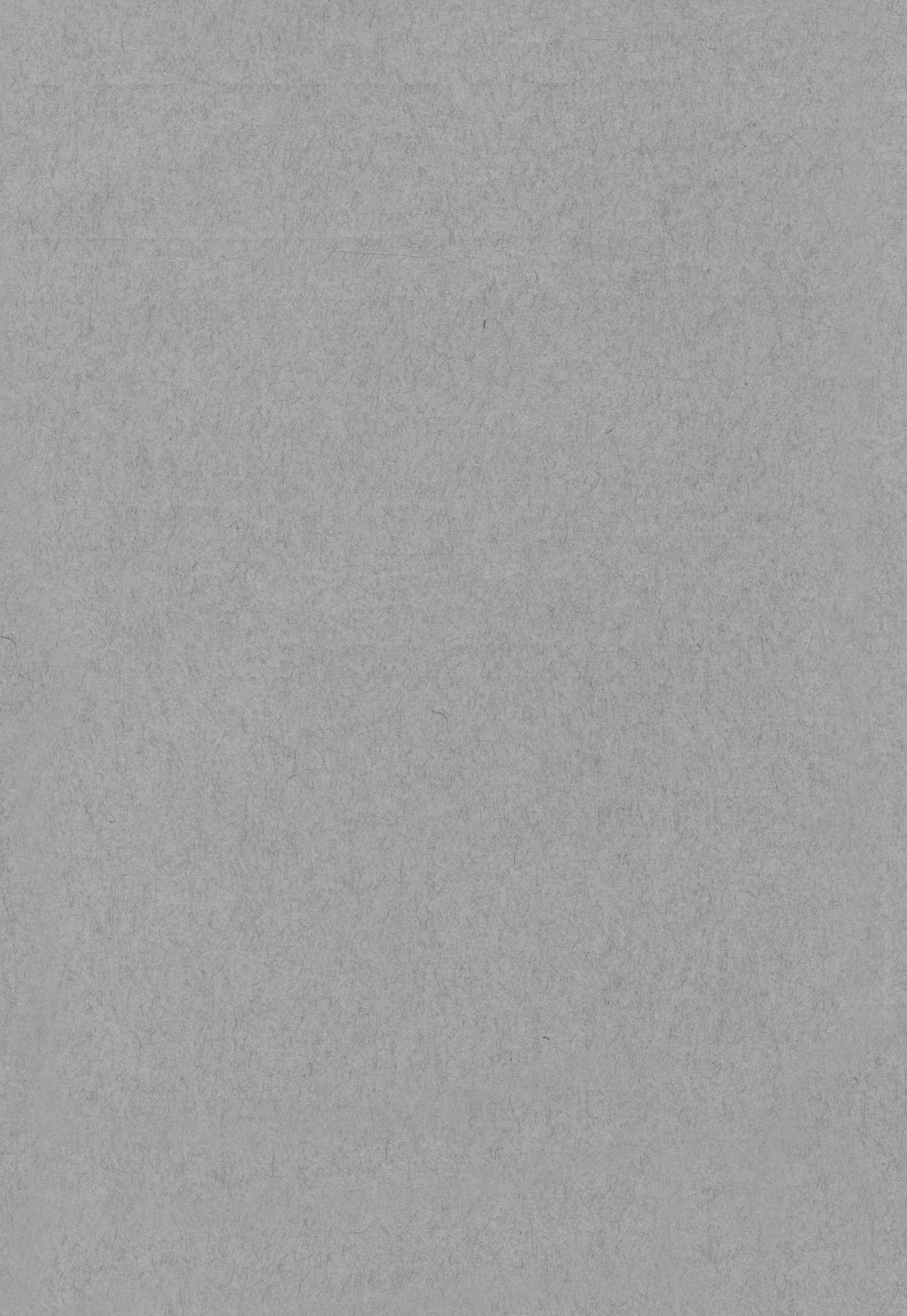

